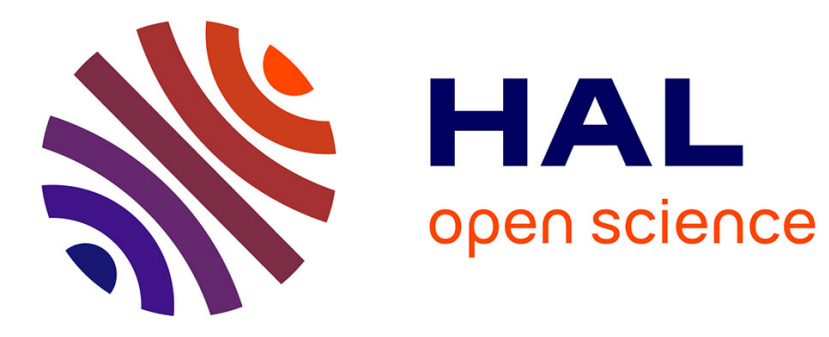

\title{
Total Synthesis of Tedarene A
}

Kelly Maurent, Corinne Vanucci-Bacqué, Nathalie Saffon-Merceron, Michel

Baltas, Florence Bedos-Belval

\section{To cite this version:}

Kelly Maurent, Corinne Vanucci-Bacqué, Nathalie Saffon-Merceron, Michel Baltas, Florence BedosBelval. Total Synthesis of Tedarene A. Journal of Natural Products, 2017, 80 (5), pp.1623-1630. 10.1021/acs.jnatprod.7b00199 . hal-02444243

\section{HAL Id: hal-02444243 \\ https://hal.science/hal-02444243}

Submitted on 22 Jan 2021

HAL is a multi-disciplinary open access archive for the deposit and dissemination of scientific research documents, whether they are published or not. The documents may come from teaching and research institutions in France or abroad, or from public or private research centers.
L'archive ouverte pluridisciplinaire HAL, est destinée au dépôt et à la diffusion de documents scientifiques de niveau recherche, publiés ou non, émanant des établissements d'enseignement et de recherche français ou étrangers, des laboratoires publics ou privés. 


\title{
Total Synthesis of Tedarene A
}

Kelly Maurent, ${ }^{\dagger}$ Corinne Vanucci-Bacqué ${ }^{\dagger}$ Nathalie Saffon-Merceron, ${ }^{\dagger}$ Michel Baltas, ${ }^{\dagger}$ and Florence Bedos-Belval ${ }^{\dagger *}$

†UMR CNRS 5068, LSPCMIB, Université Paul Sabatier, 118 route de Narbonne, Toulouse, 31062 Cedex 9, France

* Institut de Chimie de Toulouse, ICT FR 2599, Université Paul Sabatier - Toulouse III, Toulouse 31062 Cedex 9, France

\begin{abstract}
Tedarene A is a macrocyclic diaryl ether heptanoid isolated from the marine sponge Tedania ignis and showing an inhibitory effect against nitric oxide production. The first total synthesis of tedarene A was achieved starting from the commercially available 3-(4methoxyphenyl)propan-1-ol in 9 steps and $15.3 \%$ overall yield. The synthetic sequence featured an E,Z-dienic bond introduction and a macrocylization under Ullman conditions. During the synthesis, the $E, E$-isomer of tedarene A was also obtained and fully characterized.
\end{abstract}


Natural and synthetic macrocycles have attracted growing attention in drug discovery and medicinal chemistry due to their favorable pharmacological properties. ${ }^{1,2,3}$ Among them, the cyclic diarylheptanoids have been reported to mediate diverse remarkable biological activities including antioxidant, anti-inflammatory, antiviral and anticancer ones. ${ }^{4,5,6}$ Diarylheptanoids are typical secondary metabolites widely distributed in plants that possess a 1,7diphenylheptane structural skeleton. Three subgroups can be distinguished i.e. linear diarylheptanoids from which the most known is curcumin, ${ }^{7}$ cyclic biphenyl $([7,0]-$ metacyclophanes) such as myricanone ${ }^{8}$ and cyclic diphenylethers that harbor a 14-oxa-[7,1]metaparacyclophane architecture with acerogenin $\mathrm{A}^{9}$ or $\mathrm{C}^{10}$ as examples (Figure 1). Among the cyclic diaryletherheptanoid (DAEH) family, tedarene A (Figure 1) was recently isolated ${ }^{11}$ from the marine sponge Tedania ignis, commonly named the fire sponge. It is the first DAEH extracted from a marine organism. Tedarene A shows an inhibitory activity on nitric oxide production ${ }^{11}$ that may have therapeutic utility to treat inflammatory pathologies. In view of its pharmacological activity, the total synthesis of tedarene A represents an attractive challenge for chemists as a way to provide sufficient amounts of pure product for further biological assays. The unique structure of tedarene A comprises a 15-membered diaryl ether macrocycle displaying a phenol ring and an E,Z-conjugated diene unit in the seven-membered aliphatic chain. Herein, the first total synthesis of tedarene A is described. The key steps involve macrocyclization based on Ullmann coupling conditions and the regio- and stereoselective introduction of the two conjugated $E, Z$-alkene bonds by sequentially controlled reduction and elimination steps. 
<smiles>COc1cc(/C=C/C(=O)/C=C(O)/C=C/c2ccc(O)c(OC)c2)ccc1O</smiles>

Curcumin

Acerogenin A $\mathrm{R}=\mathrm{H}$ and $\mathrm{OH}(\mathrm{S})$ Acerogenin $C R=O$<smiles>COc1cc(-c2cc(CCC(=O)CCCCc3cc(O)c(O)c(OC)c3O)ccc2O)cc(O)c1OC</smiles>

Myricanone

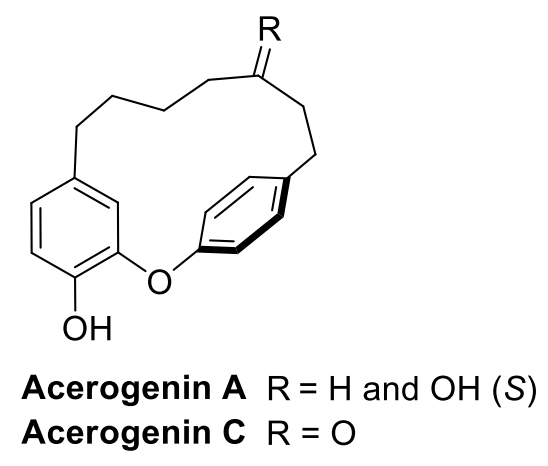<smiles>Oc1ccc2cc1Oc1ccc(cc1)CC/C=C\C=C/2</smiles>

Tedarene A

Figure 1. Representative diarylheptanoid natural products.

\section{RESULTS AND DISCUSSION}

As shown in the retrosynthetic analysis outlined in Scheme 1, we envisioned that tedarene A (1) could be obtained by a stereocontrolled dehydration of $E$-allylic alcohol 2 giving rise to the conjugated E,Z-diene moiety. The macrocyclic core of $\mathbf{2}$ could result from an intramolecular Ullmann condensation of the linear bromophenol 3. In turn, the $E$-double bond of $\mathbf{3}$ could stem from the controlled trans-hydrogenation of the propargyl alcohol 4. The latter could be readily accessed by condensation of the acetylide anion of alkyne 5 on the protected aldehyde $\mathbf{6}$.

Scheme 1. First Retrosynthetic Approach to Tedarene A (1) 


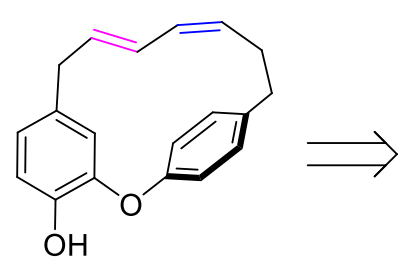

1: Tedarene A<smiles>Oc1ccc(C/C=C/C(O)CCCc2ccc(O)cc2)cc1</smiles>

2<smiles>C=CC=C</smiles><smiles>Cc1ccc(C/C=C/C(O)CCCc2ccc(O)cc2)cc1Br</smiles><smiles>C=CC=C</smiles><smiles>C#CCc1ccc(OC)c(Br)c1</smiles>

5

6

Our synthesis of the propargyl compound 5 started with 3-bromo-4-methoxybenzaldehyde as shown in Scheme 2. Ethynylation by the acetylide anion of propargyltrimethylsilane provided alcohol 7 in $95 \%$ yield. Deoxygenation was readily achieved in $91 \%$ yield by treatment with catalytic heteropolyacid $\mathrm{H}_{3}\left[\mathrm{PW}_{12} \mathrm{O}_{40}\right] \cdot n \mathrm{H}_{2} \mathrm{O}$ in the presence of triethylsilane in dichloroethane. ${ }^{12}$ It is of note that the trimethylsilyl alkyne 8a was obtained in mixture with the unexpected triethylsilyl analogue $\mathbf{8 b}$ (75/25 ratio) in $91 \%$ overall yield. This result was of no consequence on the synthesis as the next step consisted of a desilylation reaction. Initial treatment of a mixture of $\mathbf{8 a}$ and $\mathbf{8 b}$ with TBAF in THF at $0{ }^{\circ} \mathrm{C}$ led to allene $\mathbf{9}$ quantitatively. Alternative treatment with $\mathrm{K}_{2} \mathrm{CO}_{3}$ in $\mathrm{MeOH}$ at $0{ }^{\circ} \mathrm{C}$ afforded a mixture of the expected compound 5 along with allene $\mathbf{9}$ and the starting triethylsilane $\mathbf{8 b}$ in a 60/20/20 ratio. Fortunately, addition of acetic acid in the presence of TBAF allowed circumvention of the formation of allene 9. ${ }^{13}$ After optimization of the reaction conditions (3 additions of the reactants TBAF and AcOH spread over 6 days), the expected alkyne 5 was obtained in $87 \%$ yield. 


\section{Scheme 2. Synthesis of Alkene 5}<smiles>COc1ccc(C=O)cc1Br</smiles><smiles>C#CCc1ccc(OC)c(Br)c1</smiles>

The required aldehyde 6 (Scheme 3) was obtained starting with the demethylation of 4-(4methoxyphenyl)butanoic acid using hydrobromic acid in acetic acid at $150{ }^{\circ} \mathrm{C}$ to give rise to phenol 10 in $96 \%$ yield as previously described. ${ }^{14}$ The regioselective protection of the phenol function as a $t$-butyldimethylsilyl ether was achieved by reaction with TBDMSCl in the presence of imidazole in DMF followed by treatment with $\mathrm{K}_{2} \mathrm{CO}_{3}$ in a $\mathrm{MeOH} / \mathrm{H}_{2} \mathrm{O}$ mixture. ${ }^{15}$ Acid 11 obtained in 78\% yield was then reduced to alcohol 12 using $\mathrm{LiAlH}_{4}$ in $98 \%$ yield. Subsequent oxidation with IBX finally gave aldehyde 6 in $62 \%$ yield.

\section{Scheme 3. Synthesis of Aldehyde 6}

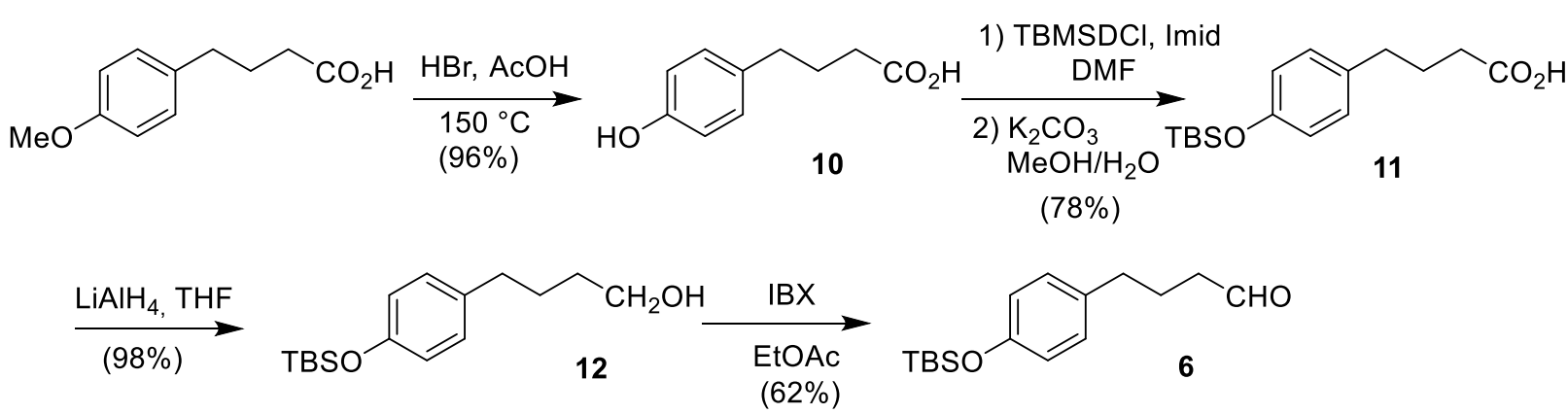

With compounds 5 and $\mathbf{6}$ in hand, we next examined the addition of the acetylide anion of $\mathbf{5}$ on aldehyde 6. We first carried out the reaction in the presence of EtMgBr in THF. ${ }^{16}$ No addition product was formed. The use of Carreira conditions $\left(\mathrm{Zn}(\mathrm{OTf})_{2}, \mathrm{NEt}_{3} \text { in toluene }\right)^{17}$ equally failed to deliver the target compound. In both cases, starting materials were totally recovered. We next 
conducted the reaction using LDA as the base at $-78{ }^{\circ} \mathrm{C} .{ }^{18}$ Attempts were made by varying the reaction temperature, reaction time and the order of addition of the reagents. Unfortunately, this reaction was found to be not reproducible with the formation of trace amounts of the expected compound along with various amounts of allene $\mathbf{9}$.

To overcome this failure due to the presence of acidic benzylic protons in alkyne $\mathbf{5}$, we turned our attention to an alternative strategy for the synthesis of tedarene A as depicted in Scheme 4. The retrosynthetic strategy was still based on an intramolecular Ullmann cyclization. However, the timing of the formation of the double bonds was reversed. So, the $E$-alkene bond was envisonned to result from dehydration of the macrocyclic allylic alcohol $\mathbf{1 3}$ obtained by an Ullmann cyclization on bromophenol 14. The Z-double bond of $\mathbf{1 4}$ would arise from a stereocontrolled hydrogenation of the propargyl alcohol 15. The latter derivative was to be obtained more efficiently by condensing the acetylide anion of alkyne $\mathbf{1 7}$ onto aldehyde $\mathbf{1 6}$. This strategy overcomes the problems arising from the acidic benzylic protons of alkyne $\mathbf{5}$ under basic conditions and was expected to efficiently lead to the target tedarene A.

\section{Scheme 4. Second Retrosynthetic Approach to Tedarene A (1)}
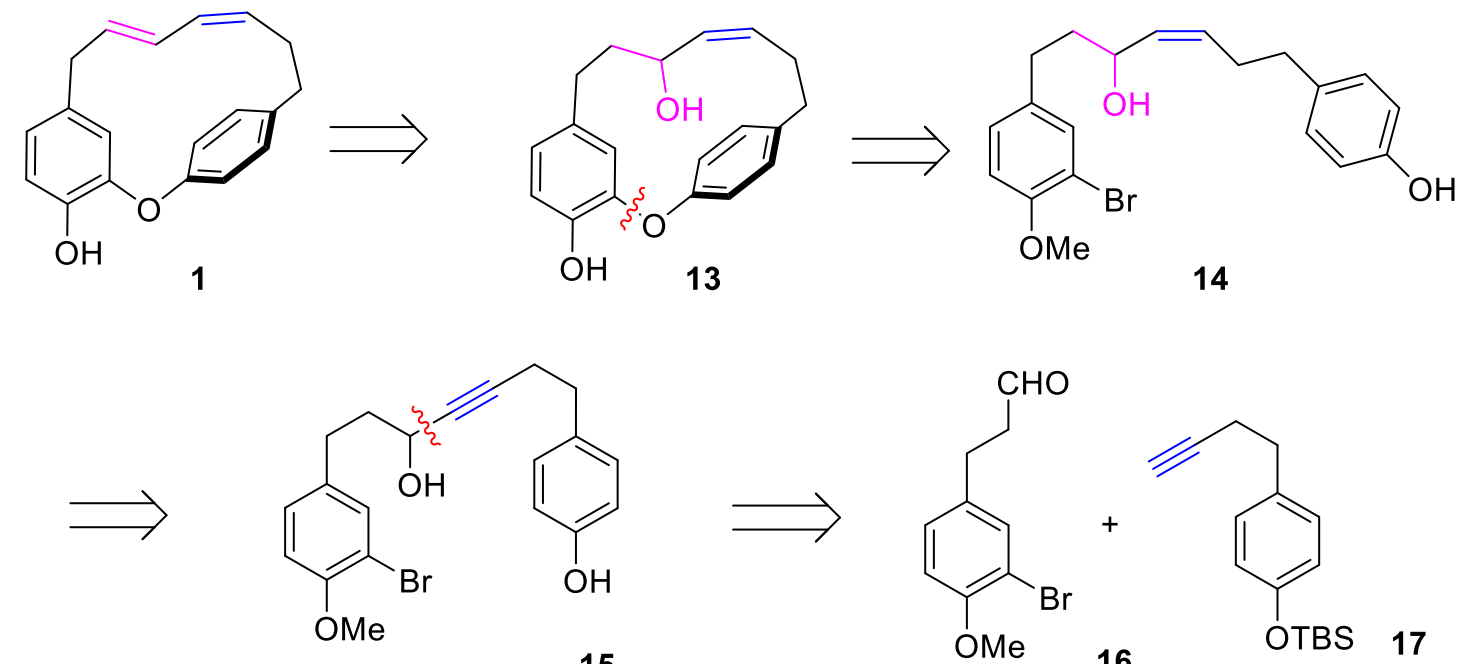

15

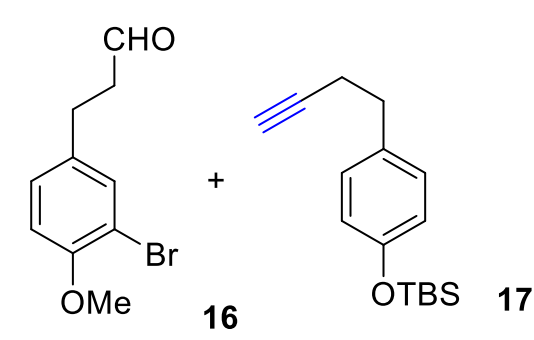

Bromoaldehyde 16 was synthetized in two steps starting from 3-(4-methoxyphenyl)propan-1ol (Scheme 5). The regioselective monobromination of the aromatic ring by treating with bromine and aluminium chloride in $\mathrm{CH}_{2} \mathrm{Cl}_{2}$ and subsequent IBX oxidation of the resulting alcohol 18 led to the expected aldehyde $\mathbf{1 6}$ in $96 \%$ yield over two steps.

\section{Scheme 5. Synthesis of Aldehyde 16}


<smiles>COc1ccc(CCCO)cc1</smiles>

Alkyne 17 was readily obtained from the commercially available 4-hydroxybenzaldehyde via a known three-step sequence. ${ }^{19}$

The acetylide anion of compound 17, efficiently formed by action of $n$-BuLi, was then condensed onto aldehyde 16 in THF to afford the expected propargyl alcohol 19 in $87 \%$ yield (Scheme 6). The controlled and stereospecific hydrogenation of the alkyne bond to a Z-double one was first envisioned by using $15 \% \mathrm{w} / \mathrm{w}$ Lindlar catalyst in the presence of $6 \%$ quinoline at $1 \mathrm{~atm}$, in $\mathrm{MeOH}$ for $12 \mathrm{~h} .{ }^{20}$ Under these conditions, the starting material was fully recovered. The expected transformation was then carried out under the same conditions without quinoline. The observed conversion rate (evaluated by ${ }^{1} \mathrm{H}$ NMR) was $31 \%$. Increasing the reaction time to $24 \mathrm{~h}$ enhanced the conversion rate to $50 \%$. However, the hydrogenation efficiency was not improved by increasing the reaction time up to $90 \mathrm{~h}$ or the catalyst amount up to $30 \% \mathrm{w} / \mathrm{w}$. Raising the hydrogen pressure to $3 \mathrm{~atm}$ for $24 \mathrm{~h}$ increased the conversion to $81 \%$. Finally, optimized conditions ( 6 atm for $18 \mathrm{~h}$ ) led to Z-alkene $\mathbf{2 0}$ in $99 \%$ isolated yield.

Cleavage of the TBS group of $\mathbf{2 0}$ was readily accomplished in $94 \%$ yield by treatment with TBAF in THF. Subsequent intramolecular Ullman cyclization on bromophenol $\mathbf{1 4}$ was achieved in the presence of $\mathrm{CuO}$ and $\mathrm{K}_{2} \mathrm{CO}_{3}$ in refluxing pyridine for $48 \mathrm{~h} .{ }^{21}$ Under these conditions, ring closure afforded macrocyclic compound 21 in good $70 \%$ yield. In order to reduce the reaction time, the cyclization was carried out under microwave heating. ${ }^{22}$ The reaction was complete at $150{ }^{\circ} \mathrm{C}$ in $4 \mathrm{~h}$ and $\mathbf{2 1}$ was obtained in $81 \%$ an improved yield. The cyclic structure of $\mathbf{2 1}$ was confirmed by the typical shield shift of the $\mathrm{H}^{2}$ resonance (Scheme 6) shown in the ${ }^{1} \mathrm{H}$ NMR spectrum as a result of the anisotropic effect of the neighboring $\operatorname{aromatic} \operatorname{ring}^{21}\left(\delta \mathrm{H}^{2}=5.38 \mathrm{ppm}\right.$ in 21 vs. $\delta \mathrm{H} 2=7.33 \mathrm{ppm}$ in 14). 
Scheme 6. Synthesis of the Macrocyclic Core of Tedarene A<smiles>COc1ccc(CCC=O)cc1Br</smiles>

16

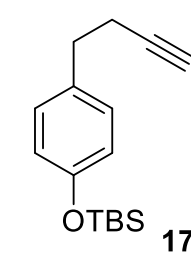

$\underset{(87 \%)}{\stackrel{n-B u L i, ~ T H F}{\longrightarrow}}$ 17<smiles>COc1ccc(CCC(O)C#CCCc2ccc(OC(C)(C)C)cc2)cc1Br</smiles>

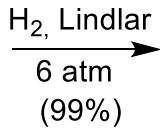<smiles>COc1ccc(CC/C=C\C(O)CCc2ccc(O)c(Br)c2)cc1</smiles>
TBAF, THF $(94 \%)$

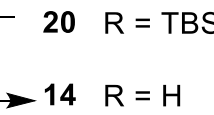

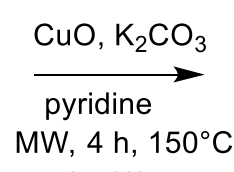

$(81 \%)$

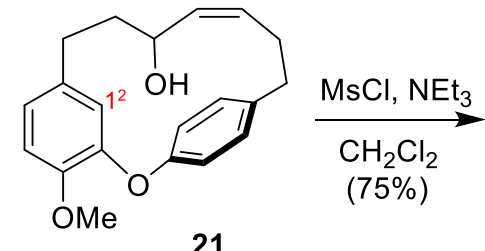

21

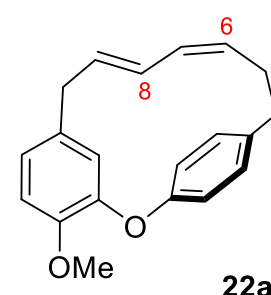

22a

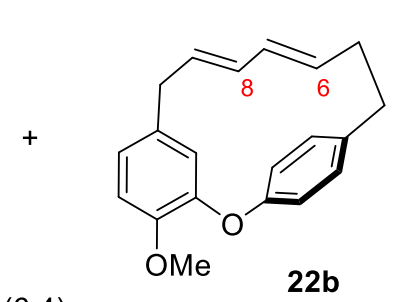

$(6: 4)$

At this point, the required $E$-alkene bond was expected to result from the stereospecific dehydration of the allylic alcohol 21. Treatment with mesyl chloride in the presence of $\mathrm{NEt}_{3}$ in $\mathrm{CH}_{2} \mathrm{Cl}_{2}$ from $0{ }^{\circ} \mathrm{C}$ to room temperature directly afforded ${ }^{23}$ a $60 / 40$ mixture of two diene derivatives (as estimated by ${ }^{1} \mathrm{H}$ NMR), in $75 \%$ overall yield. The use of preparative HPLC in direct phase conditions using a chiral phase column allowed the separation of the two isomers in respectively $44 \%$ and $13 \%$ isolated yields.

The ${ }^{1} \mathrm{H}$ and ${ }^{13} \mathrm{C}$ NMR spectra of the major isomer 22a appeared similar to those described for tedarene A along with some missing or hardly detectable signals at room temperature. The slow interconversion rate near the NMR time scale between the two enantiomeric conformations causes coalescence of some NMR signals at $25{ }^{\circ} \mathrm{C} .{ }^{24}$ The configurations of the double bonds, supposed to be identical to those of tedarene A i.e. $6 Z, 8 E$, was confirmed by single crystal Xray diffraction analysis of $\mathbf{2 2 a}$ (Figure 2). The NMR data of the minor isomer $\mathbf{2 2 b}$ are consistent with a $6 E, 8 E$ configuration of the diene system with a rapid interconversion of the two enantiomeric conformations at room temperature. Regarding the coupling constant for alkenes protons, $E(J=14.7 \mathrm{~Hz})$ and $Z(J=7.5 \mathrm{~Hz})$ configurations are undoubted. Macrocycle 22b afforded needle crystals that were submitted to single crystal X-ray diffraction analysis (Figure 2). The resulting data confirmed the assigned configurations, which suggest a partial isomerization of the pre-established Z-double bond presumably via a carbocation intermediate.

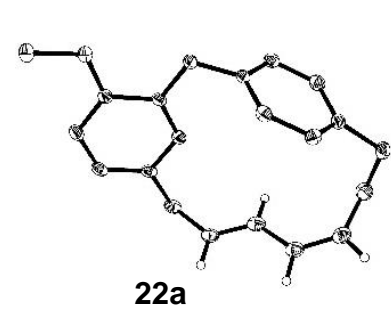

22a

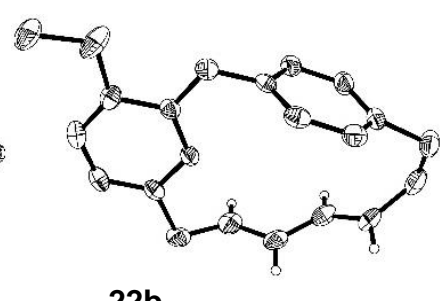

22b 
Figure 2. X-ray crystal structure of 22a and 22b. Thermal ellipsoids represent 30\% probability level. For clarity, disordered atoms and $\mathrm{H}$ atoms are omitted except the dienic and phenolic ones. $^{25}$

In order to complete the synthesis of tedarene $\mathrm{A}$, the last O-demethylation step was then attempted using standard Lewis acid conditions as already described for diarylheptanoid derivatives. Unfortunately, the use of $\mathrm{AlCl}_{3}$ in refluxing $\mathrm{CH}_{2} \mathrm{Cl}_{2}{ }^{26}$ or of $\mathrm{BBr}_{3}$ in $\mathrm{CH}_{2} \mathrm{Cl}_{2}$ at lower temperature $\left(-78^{\circ} \mathrm{C}^{27}\right.$ to $\left.-40{ }^{\circ} \mathrm{C}^{28}\right)$, led to the degradation of the starting material due to the high reactivity of the diene heptanoid moiety under these Lewis acid conditions.

Alternatively, the isomeric mixture 22a-b was treated in the presence of sodium thioethanolate in refluxing $\mathrm{DMF}^{29}$ (Scheme 7). This procedure effectively allowed the expected Odemethylation. Beside a mixture of the expected phenols $\mathbf{1}$ and $\mathbf{2 3}$, a third isomer was detected, in a 26/32/42 ratio according to ${ }^{1} \mathrm{H}$ NMR. Flash chromatography allowed us to isolate the undesired compound $\mathbf{2 4}$ along with an inseparable mixture of $\mathbf{1}$ and $\mathbf{2 3}$. The spectroscopic data of $\mathbf{2 4}$ was in accordance with a $7 E, 9 Z$ conjugated diene phenol structure, resulting from the deprotonation of the benzylic protons followed by the migration of the diene system under basic conditions.

\section{Scheme 7. Demethylation of Macrocyles 22a-b}

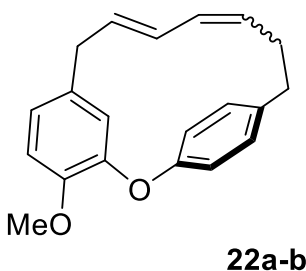

$22 a-b$

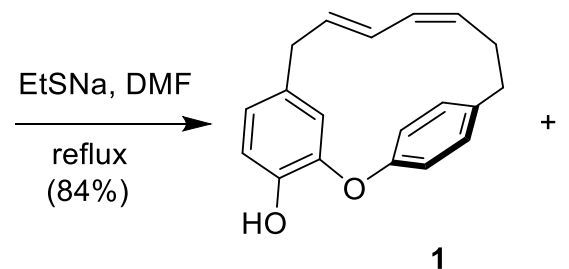

1

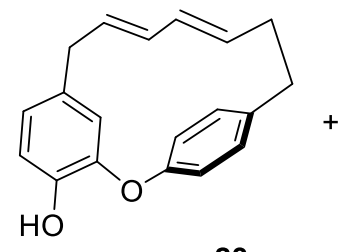

23

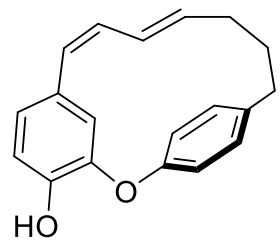

24

$(26: 32: 42)$

The formation of the unwanted derivative $\mathbf{2 4}$ prompted us to conduct the demethylation step earlier in the synthesis starting from the macrocyclic allylic alcohol 21 that does not contain any acidic benzylic protons (Scheme 8 ). When submitted to the previous demethylation conditions (EtSNa, DMF, reflux), macrocycle 21 cleanly afforded the expected phenol 13 in $79 \%$ yield. 


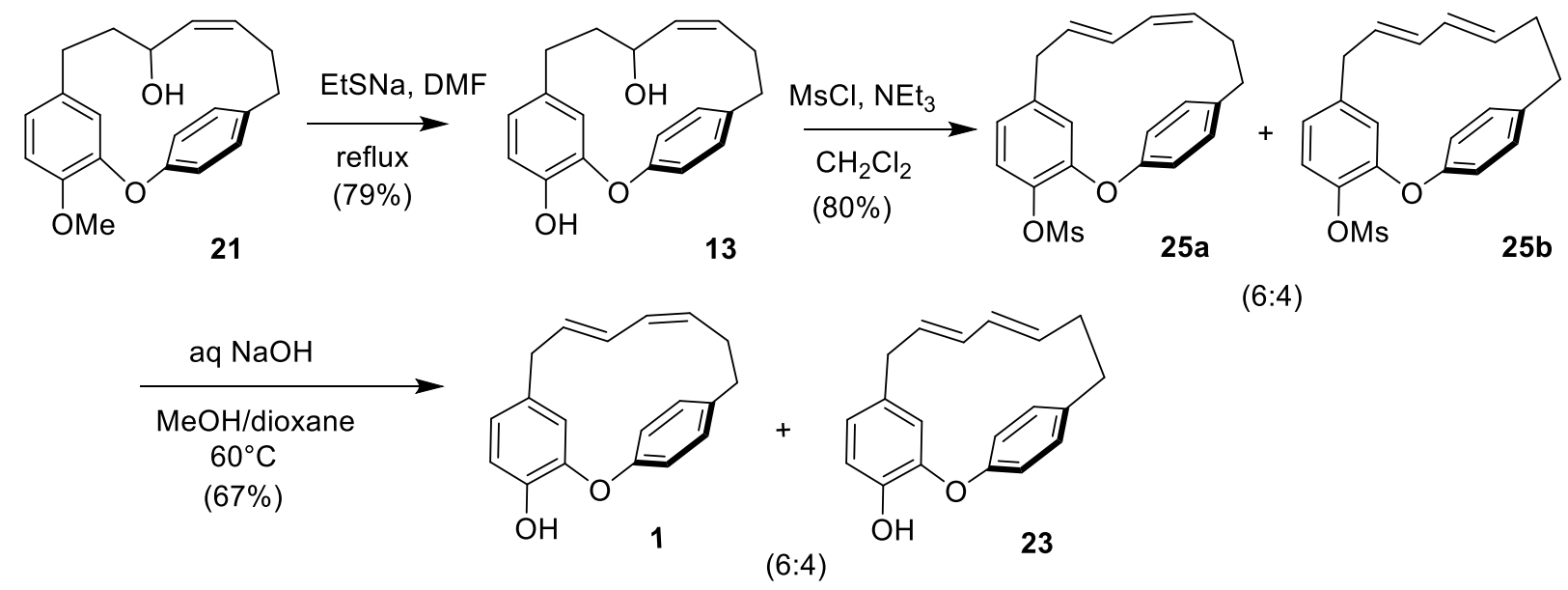

Treatment of phenolic allylic alcohol 13 with mesyl chloride in the presence of $\mathrm{NEt}_{3}$ from $0{ }^{\circ} \mathrm{C}$ to room temperature allowed the elimination reaction to proceed along with the unavoidable mesylation of the phenol leading to a mixture of diene $E, Z$ and $E, E$-isomers $25 \mathbf{a}$ and $\mathbf{2 5} \mathbf{b}$ in 60/40 ratio (as determined by ${ }^{1} \mathrm{H}$ NMR), as previously observed for the mixture of $\mathbf{2 2 a}-\mathbf{b}$, in $80 \%$ overall yield. Hydrolysis of the mesylates was finally accomplished by action of aqueous sodium hydroxide ${ }^{30}$ in an optimized $1: 1 \mathrm{MeOH}$-dioxane mixture at $60{ }^{\circ} \mathrm{C}$, in $67 \%$ overall yield. This led to a mixture of isomers $E, Z-\mathbf{1}$ and $E, E-\mathbf{2 3}$ in the same ratio as the initial mixture and with no trace of double bond migration. A challenging preparative HPLC chromatography of this mixture due to the minor structure differences, using a chiral phase column in direct phase allowed the separation of the two macrocycles $\mathbf{1}$ and $\mathbf{2 3}$ in $38.5 \%$ and $23 \%$ respective isolated yields. The spectroscopic data of $\mathbf{1}$, in particular the ${ }^{1} \mathrm{H}$ and ${ }^{13} \mathrm{C}$ NMR spectra in $\mathrm{CD}_{3} \mathrm{OD}$ recorded at $25{ }^{\circ} \mathrm{C}$ and $-40{ }^{\circ} \mathrm{C}$, were in full agreement with those published for the naturally occurring tedarene A. ${ }^{11}$ Moreover, both isomers crystallized from $\mathrm{CH}_{2} \mathrm{Cl}_{2}$ to give colorless crystals that were suitable for single crystal X-ray diffraction analysis (Figure 3). Their respective configurations was unambiguously confirmed by this analysis.

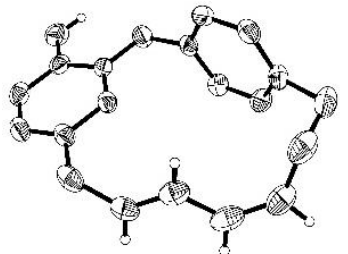

1

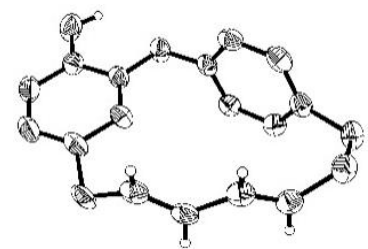

23 
Figure 3. X-ray structures of $\mathbf{1}$ and 23. Thermal ellipsoids represent 30\% probability level. The asymmetric unit contains two independent molecules, only one is shown here. For clarity, disordered atoms and $\mathrm{H}$ atoms are omitted except the diene and phenolic ones. ${ }^{25}$

In summary, we have completed the first total synthesis of the natural product tedarene A. The envisioned optimized strategy proceeded in nine steps and $15.3 \%$ overall yield from commercially available 3-(4-methoxyphenyl)propan-1-ol. The regio- and stereocontrol of the dienic system as well as the intramolecular Ullmann macrocylization represent the key features of this total synthesis. The previously unknown $E, E$-isomer of tedarene A was also prepared and fully characterized. This efficient synthesis provides convenient access to tedarene A for further biological assays and paves the way for the preparation of analogues for further SAR studies.

\section{EXPERIMENTAL SECTION}

General Experimental Procedures. Unless otherwise noted, all experiments were carried out under a nitrogen atmosphere. Solvents $\left(\mathrm{CH}_{2} \mathrm{Cl}_{2}\right.$ and THF) were dried via a purification solvent system MB-SP- 800 (MBRAUN). Melting points (mp) were obtained on a Buchi apparatus and are uncorrected. Measurements above $200^{\circ} \mathrm{C}$ were not possible with this apparatus. UV spectra were recorded in $\mathrm{MeOH}$ on a Hewlett Packard 8453 spectrometer at $25^{\circ} \mathrm{C}$. IR spectra were recorded on a Thermo Nicolet Nexus spectrometer. NMR spectra were recorded on Brucker Avance 300 and $500 \mathrm{MHz}$ spectrometers. The NMR spectra were acquired in $\mathrm{CDCl}_{3}$ and $\mathrm{CD}_{3} \mathrm{OD}$, and the chemical shifts were reported in parts per million referring to $\mathrm{CHCl}_{3}\left(\delta_{\mathrm{H}} 7.26\right.$ for proton and $\delta_{\mathrm{C}} 77.0$ for carbon) and $\mathrm{MeOH}\left(\delta_{\mathrm{H}} 3.34\right.$ for proton and $\delta_{\mathrm{C}} 49.0$ for carbon), respectively. Signals are described as follow: s, singlet; brs, broad signal; d, doublet; t, triplet; m, multiplet. HRMS data were recorded on a Xevo G2 QTOF (Waters) instrument. Reactions were monitored by TLC on silica gel Alugram® Xtra SIL G/UV ${ }_{254}$. Column chromatography were performed on Machery-Nagel silica gel 0.063-0.2 mm. Flash chromatography purification was performed on Puriflash 430 (Interchim) equipped with a $30 \mu \mathrm{m}$ silica gel column PF30SIHP-JP (Interchim). HPLC purification was performed using a system equipped with an UV detector. The column used was a ChiralPak IA for SFC $(250 \times 20 \mathrm{~mm}, 5 \mu \mathrm{m})$. Reactions utilizing microwave technology were conducted in a CEM Discover Benchmate microwave reactor (model no. 908010). 
1-(3-Bromo-4-methoxyphenyl)-3-(trimethylsilyl)prop-2-yn-1-ol (7). To a solution of propargyl trimethylsilane $(854 \mu \mathrm{L}, 6.05 \mathrm{mmol})$ in dry $\mathrm{THF}(30 \mathrm{~mL})$ at $-78{ }^{\circ} \mathrm{C}$ under a $\mathrm{N}_{2}$ atmosphere was added dropwise $n$-BuLi (1.6 $\mathrm{M}$ in hexanes, $3.78 \mathrm{~mL}, 6.05 \mathrm{mml}$ ). The reaction mixture was stirred for $45 \mathrm{~min}$ and a solution of 3-bromo-4-methoxybenzaldehyde (1 g, $4.65 \mathrm{mmol})$ in THF $(10 \mathrm{~mL})$ was added dropwise. The reaction was allowed to warm to $0{ }^{\circ} \mathrm{C}$ and quenched with satd aq $\mathrm{NH}_{4} \mathrm{Cl}$ solution. The aqueous layer was extracted with EtOAc. The combined organic layers were washed with satd aq $\mathrm{NH}_{4} \mathrm{Cl}$ solution, $\mathrm{H}_{2} \mathrm{O}$, brine, dried over $\mathrm{Na}_{2} \mathrm{SO}_{4}$, and concentrated under reduced pressure. The crude residue was purified by column chromatography on silica gel $(\mathrm{EtOAc} / \mathrm{PE}=1: 9)$ to provide propargyl alcohol $7(1.39 \mathrm{~g}, 95 \%)$ as a light yellow oil. $\mathrm{R}_{f}=0.41(\mathrm{EtOAc} / \mathrm{PE}=2: 8)$; IR (neat) $3370,2173 \mathrm{~cm}^{-1} ;{ }^{1} \mathrm{H} \mathrm{NMR}\left(\mathrm{CDCl}_{3}\right.$, $300 \mathrm{MHz}) \delta 7.73(\mathrm{~d}, 1 \mathrm{H}, J=1.8 \mathrm{~Hz}), 7.44(\mathrm{dd}, 1 \mathrm{H}, J=8.4,1.8 \mathrm{~Hz}), 6.89(\mathrm{~d}, 1 \mathrm{H}, \quad J=8.4 \mathrm{~Hz})$, $5.38(\mathrm{~d}, 1 \mathrm{H}, J=6 \mathrm{~Hz}), 3.90(\mathrm{~s}, 3 \mathrm{H}), 2.23(\mathrm{~d}, 1 \mathrm{H}, J=6 \mathrm{~Hz}), 0.21(\mathrm{~s}, 9 \mathrm{H}) ;{ }^{13} \mathrm{C} \mathrm{NMR}\left(\mathrm{CDCl}_{3}, 75\right.$ MHz) $\delta 155.9,134.1,132.0,127.1,111.8,111.7,104.7,92.0,63.9,56.4,-0.1$; HRMS (ESI) : $m / z, 295.0150\left[\mathrm{M}+\mathrm{H}-\mathrm{H}_{2} \mathrm{O}\right]^{+}$(calcd for $\mathrm{C}_{13} \mathrm{H}_{16} \mathrm{BrOSi}, 295.0154$ ).

(3-(3-Bromo-4-methoxyphenyl)prop-1-yn-1-yl)trimethylsilane (8a) and (3-(3-bromo-4methoxyphenyl)prop-1-yn-1-yl)triethylsilane $(\mathbf{8 b})$. To solution of propargyl alcohol 7 (1.2 g, $3.85 \mathrm{mmol})$ in 1,2-dichloroethane $(12 \mathrm{~mL})$ was added $\mathrm{H}_{3} \mathrm{PW}_{12} \mathrm{O}_{4} \cdot \mathrm{nH}_{2} \mathrm{O}\left(111 \mathrm{mg}, 3.9510^{-2}\right.$ $\mathrm{mmol})$ then $\mathrm{Et}_{3} \mathrm{SiH}(0.92 \mathrm{~mL}, 5.77 \mathrm{mmol})$. The reaction mixture was heated at $50{ }^{\circ} \mathrm{C}$ for $2 \mathrm{~h}$. After cooling to room temperature, the mixture was quenched with satd aq $\mathrm{NaHCO}_{3}$ solution. The aqueous layer was extracted $\mathrm{CH}_{2} \mathrm{Cl}_{2}$. The combined organic layers were washed with satd aq $\mathrm{NaHCO}_{3}$ solution, $\mathrm{H}_{2} \mathrm{O}$, brine, dried over $\mathrm{Na}_{2} \mathrm{SO}_{4}$, and concentrated under reduced pressure. The crude residue was purified by column chromatography on silica gel (EtOAc/PE $=3: 97)$ to provide an inseparable (73/27) mixture of trimethyl and triethylsilyl compounds $\mathbf{8 a}$ and $\mathbf{8 b}(0.95$ $\mathrm{g}, 91 \%)$ as colorless oil. $\mathrm{R}_{f}=0.65(\mathrm{EtOAc} / \mathrm{PE}=2: 8)$; IR (neat) $2176 \mathrm{~cm}^{-1}$; For $8 \mathbf{a}$ (From a mixture) ${ }^{1} \mathrm{H}$ NMR $\left(\mathrm{CDCl}_{3}, 300 \mathrm{MHz}\right) \delta 7.51(\mathrm{~d}, 1 \mathrm{H}, J=2.2 \mathrm{~Hz}), 7.24(\mathrm{dd}, 1 \mathrm{H}, J=8.4,2.2$ $\mathrm{Hz}), 6.85(\mathrm{~d}, 1 \mathrm{H}, J=8.4 \mathrm{~Hz}), 3.88(\mathrm{~s}, 3 \mathrm{H}), 3.57(\mathrm{~s}, 2 \mathrm{H}), 0.19(\mathrm{~s}, 9 \mathrm{H}) ;{ }^{13} \mathrm{C} \mathrm{NMR}\left(\mathrm{CDCl}_{3}, 75\right.$

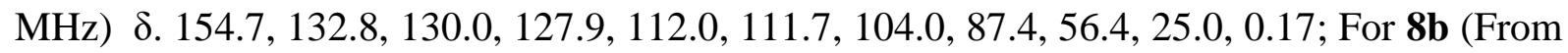
a mixture) ${ }^{1} \mathrm{H}$ NMR $\left(\mathrm{CDCl}_{3}, 300 \mathrm{MHz}\right) \delta 7.55(\mathrm{~d}, 1 \mathrm{H}, J=2.2 \mathrm{~Hz}), 7.24(\mathrm{dd}, 1 \mathrm{H}, J=8.4,2.2$ $\mathrm{Hz}), 6.85(\mathrm{~d}, 1 \mathrm{H}, J=8.4 \mathrm{~Hz}), 3.88(\mathrm{~s}, 3 \mathrm{H}), 3.60(\mathrm{~s}, 2 \mathrm{H}), 1.01(\mathrm{t}, 9 \mathrm{H}, J=7.8 \mathrm{~Hz}), 0.62(\mathrm{qd}, 6 \mathrm{H}$, $J=7.8,0.8 \mathrm{~Hz}) ;{ }^{13} \mathrm{C} \mathrm{NMR}\left(\mathrm{CDCl}_{3}, 75 \mathrm{MHz}\right) \delta 154.6,132.8,130.2,127.8,111.9,111.6,104.9$, 84.8, 56.4, 25.1, 7.6, 4.6. 
2-Bromo-1-methoxy-4-(propa-1,2-dienyl)benzene (9). A 73/27 mixture of derivatives 8a-8b (232 mg, $0.78 \mathrm{mmol})$ was dissolved in dry THF $(10 \mathrm{~mL})$ and cooled to $0{ }^{\circ} \mathrm{C}$. A TBAF solution (1M in THF, $1.56 \mathrm{~mL}, 1.56 \mathrm{mmol}$ ) was added dropwise. The reaction mixture, which turned red immediately, was warmed to rt and stirred for $1 \mathrm{~h}$. Water was added and the aqueous layer was extracted with EtOAc. The combined organic layers were washed with $\mathrm{H}_{2} \mathrm{O}$, brine and dried over $\mathrm{Na}_{2} \mathrm{SO}_{4}$. Concentration under reduced pressure provided allene $\mathbf{9}(171 \mathrm{mg}, 97 \%)$ as a yellow oil which was pure enough for use without further purification. $\mathrm{R}_{f}=0.32(\mathrm{EtOAc} / \mathrm{PE}$ = 5:95); IR (neat) $1941 \mathrm{~cm}^{-1} ;{ }^{1} \mathrm{H} \mathrm{NMR}\left(\mathrm{CDCl}_{3}, 300 \mathrm{MHz}\right) \delta 7.49(\mathrm{~d}, 1 \mathrm{H}, J=2.1 \mathrm{~Hz}), 7.17(\mathrm{dd}$, $1 \mathrm{H}, J=8.4,2.1 \mathrm{~Hz}), 6.84(\mathrm{~d}, 1 \mathrm{H}, J=8.4 \mathrm{~Hz}), 6.06(\mathrm{t}, 1 \mathrm{H}, J=6.8 \mathrm{~Hz}), 5.16(\mathrm{~d}, 2 \mathrm{H}, J=6.8 \mathrm{~Hz})$, $3.88(\mathrm{~s}, 3 \mathrm{H}) ;{ }^{13} \mathrm{C} \mathrm{NMR}\left(\mathrm{CDCl}_{3}, 75 \mathrm{MHz}\right) \delta 209.5,154.9,131.4,127.9,126.8,112.2,112.1$, 92.6, 79.4, 56.34; HRMS (DCI, $\left.\mathrm{CH}_{4}\right): \mathrm{m} / z 224.9912[\mathrm{M}]^{+}$(calcd for $\mathrm{C}_{10} \mathrm{H}_{9} \mathrm{BrO}, 223.9837$ ).

2-Bromo-1-methoxy-4-(prop-2-ynyl)benzene (5). A 73/27 mixture of derivatives 8a-8b (1.26 g, $4.07 \mathrm{mmol})$ was dissolved in dry THF $(40 \mathrm{~mL})$ and cooled to $0{ }^{\circ} \mathrm{C}$. AcOH $(1.16 \mathrm{~mL}, 20 \mathrm{mmol})$ and TBAF solution (1M in THF, $16.3 \mathrm{~mL}, 16.3 \mathrm{mmol}$ ) were added dropwise and the reaction mixture was allowed to warm to rt. Two supplementary additions of AcOH (0.7 mL, 12.2 mmol) and TBAF solution $(8.15 \mathrm{~mL}, 8.15 \mathrm{mmol})$ were realized after stirring for $48 \mathrm{~h}$ and $96 \mathrm{~h}$. After 6 days of reaction time at $\mathrm{rt}, \mathrm{H}_{2} \mathrm{O}$ was added and the aqueous layer was extracted with EtOAc. The combined organic layers were washed with satd aq $\mathrm{NaHCO}_{3}$ solution, $\mathrm{H}_{2} \mathrm{O}$, brine, dried over $\mathrm{Na}_{2} \mathrm{SO}_{4}$, and concentrated under reduced pressure. The crude residue was purified by column chromatography on silica gel $(\mathrm{EtOAc} / \mathrm{PE}=5: 95)$ to provide alkyne $\mathbf{5}(772 \mathrm{mg}, 87 \%)$ as a yellow oil. $\mathrm{R}_{f}=0.38(\mathrm{EtOAc} / \mathrm{PE}=1: 9) ; \mathrm{IR}$ (neat) $3271 \mathrm{~cm}^{-1} ;{ }^{1} \mathrm{H} \mathrm{NMR}\left(\mathrm{CDCl}_{3}, 300 \mathrm{MHz}\right)$ $\delta 7.54(\mathrm{~d}, 1 \mathrm{H}, J=1.9 \mathrm{~Hz}), 7.24(\mathrm{dd}, 1 \mathrm{H}, J=8.4,1.9 \mathrm{~Hz}), 6.85(\mathrm{~d}, 1 \mathrm{H}, \quad J=8.4 \mathrm{~Hz}), 3.88(\mathrm{~s}, 3 \mathrm{H})$, $3.53(\mathrm{~d}, 2 \mathrm{H}, J=2.75 \mathrm{~Hz}), 2.20(\mathrm{t}, 1 \mathrm{H}, J=2.75 \mathrm{~Hz}) ;{ }^{13} \mathrm{C} \mathrm{NMR}\left(\mathrm{CDCl}_{3}, 75 \mathrm{MHz}\right) \delta 154.8,132.8$, 129.7, 127.9, 112.0, 111.7, 81.7, 70.9, 56.4, 23.7; HRMS (DCI, $\mathrm{CH}_{4}$ ) : m/z $224.9915[\mathrm{M}+\mathrm{H}]^{+}$ (calcd for $\mathrm{C}_{10} \mathrm{H}_{10} \mathrm{BrO}, 224.9912$ ).

4-(4-((tert-Butyldimethylsilyl)oxy)phenyl)butanoic acid (11). To an ice cooled solution of acid 10 (100 mg, $0.55 \mathrm{mmol})$ in dry DMF (5 mL) under $\mathrm{N}_{2}$ were added imidazole (227 mg, 3.33 mmol) and TBDMSCl (251 mg, $1.66 \mathrm{mmol})$. The reaction mixture was stirred at $0{ }^{\circ} \mathrm{C}$ for $1 \mathrm{~h}$ and allowed to warm to rt. The reaction was quenched with aq $1 \mathrm{M} \mathrm{KHSO}_{4}$ solution. The aqueous layer was extracted with EtOAc and the combined organic layers were washed with $1 \mathrm{M} \mathrm{KHSO} 4$ solution, satd aq $\mathrm{NaHCO}_{3}$ solution, $\mathrm{H}_{2} \mathrm{O}$ and brine, dried over $\mathrm{Na}_{2} \mathrm{SO}_{4}$ and 
concentrated under reduced pressure. $\mathrm{K}_{2} \mathrm{CO}_{3}(115 \mathrm{mg}, 0.83 \mathrm{mmol})$ in $\mathrm{H}_{2} \mathrm{O}(1.5 \mathrm{~mL})$ was added to a solution of the obtained crude disilylate in THF $(3 \mathrm{~mL})$ and $\mathrm{MeOH}(1.5 \mathrm{~mL})$. The mixture was stirred at $\mathrm{rt}$ for $12 \mathrm{~h}$. After dilution with EtOAc, the organic layer was extracted with satd aq $\mathrm{Na}_{2} \mathrm{CO}_{3}$ solution. The aqueous layer was extracted with EtOAc, acidified with conc $\mathrm{HCl}$ solution to $\mathrm{pH}=1$, and re-extracted with EtOAc. The combined organic layers were washed with $\mathrm{H}_{2} \mathrm{O}$, brine, dried over $\mathrm{Na}_{2} \mathrm{SO}_{4}$ and concentrated under reduced pressure to yield acid $\mathbf{1 1}$ (128 mg, 78\%) pure enough to be used without further purification. The physical data and NMR spectra were in agreement with the literature. ${ }^{31}$

4-(4-((tert-Butyldimethylsilyl)oxy)phenyl)butan-1-ol (12). To a suspension of $\mathrm{LiAlH}_{4}(33 \mathrm{mg}$, $0.87 \mathrm{mmol})$ in dry THF $(5 \mathrm{~mL})$ at $0{ }^{\circ} \mathrm{C}$ under $\mathrm{N}_{2}$ was added dropwise a solution of aldehyde $\mathbf{1 1}$ (128 mg, $0.43 \mathrm{mmol})$ in THF $(5 \mathrm{~mL})$. The reaction mixture was allowed to warm to $\mathrm{rt}$ and quenched with aq $3 \mathrm{M} \mathrm{HCl}$ solution. The aqueous layer was extracted with EtOAc and the combined organic layers were washed with satd aq $\mathrm{NaHCO}_{3}$ solution, brine, dried over $\mathrm{Na}_{2} \mathrm{SO}_{4}$, and concentrated under reduced pressure. Alcohol 12 (119 mg, 98\%) was obtained as yellow oil with no further purification. The physical data and NMR spectra were in agreement with the literature. $^{31}$

4-(4-((tert-Butyldimethylsilyl)oxy)phenyl)butanal (6). To a solution of alcohol 12 (1.27 g, 4.53 $\mathrm{mmol})$ in EtOAc $(30 \mathrm{~mL})$ was added IBX $(2.54 \mathrm{~g}, 9 \mathrm{mmol})$. The reaction mixture was refluxing for $3 \mathrm{~h}$ then cooled to $\mathrm{rt}$ and filtered over a Celite pad. The filtrate was concentrated under reduced pressure. The crude residue was purified by column chromatography (EtOAc/PE = 1:9) to provide aldehyde $6(787 \mathrm{mg}, 62 \%)$ as a colorless oil. The physical data and NMR spectra were in agreement with the literature. ${ }^{32}$

3-(3-Bromo-4-methoxyphenyl)propan-1-ol (18). To a solution of 3-(4-methoxyphenyl) propan1-ol (4.4 g, $26.47 \mathrm{mmol})$ in $\mathrm{CH}_{2} \mathrm{Cl}_{2}(100 \mathrm{~mL})$ were added $\mathrm{AlCl}_{3}(3.53 \mathrm{~g}, 26.47 \mathrm{mmol})$ and $\mathrm{Br}_{2}$ $(1.35 \mathrm{~mL}, 26.47 \mathrm{mmol})$ dropwise at $0{ }^{\circ} \mathrm{C}$ under $\mathrm{N}_{2}$. The reaction was allowed to stir at $0{ }^{\circ} \mathrm{C}$ for 30 min and was quenched with ice water. The aqueous layer was extracted with $\mathrm{CH}_{2} \mathrm{Cl}_{2}$. The combined organic layers were washed with $\mathrm{H}_{2} \mathrm{O}$, satd aq $\mathrm{NaHCO}_{3}$ solution, brine, dried over $\mathrm{Na}_{2} \mathrm{SO}_{4}$, and concentrated under reduced pressure. Alcohol $18(6.45 \mathrm{~g}, 99 \%)$ was obtained as a colorless oil with no further purification. $\mathrm{R}_{\mathrm{f}}=0.23(\mathrm{EtOAc} / \mathrm{EP}=2: 3)$. IR (neat) $v_{\max } 3300 \mathrm{~cm}^{-1}$. ${ }^{1} \mathrm{H} \mathrm{NMR}\left(\mathrm{CDCl}_{3}, 300 \mathrm{MHz}\right) \delta 7.39(\mathrm{~d}, 1 \mathrm{H}, J=2.1 \mathrm{~Hz}), 7.09(\mathrm{dd}, 1 \mathrm{H}, J=8.4,2.1 \mathrm{~Hz}), 6.82(\mathrm{~d}$, 
$1 \mathrm{H}, J=8.1 \mathrm{~Hz}$ ), 3.87 (s, 3H), 3.66 (t, 2H, $J=6.3 \mathrm{~Hz}$ ), 2.64 (t, 2H, $J=7.5 \mathrm{~Hz}), 1.90-1.81(\mathrm{~m}$, 2H). ${ }^{13} \mathrm{C} \mathrm{NMR}\left(\mathrm{CDCl}_{3}, 75 \mathrm{MHz}\right) \delta 154.2,135.6,133.3,128.4,112.1,111.6,62.1,56.4,34.3$, 30.9. HRMS (DCI, $\left.\mathrm{CH}_{4}\right): m / z 245.0177[\mathrm{M}+\mathrm{H}]^{+}\left(\right.$calcd for $\left.\mathrm{C}_{10} \mathrm{H}_{14} \mathrm{BrO}_{2}, 245.0162\right)$.

3-(3-Bromo-4-methoxyphenyl)propanal (16). To a solution of alcohol 18 (2 g, $8.16 \mathrm{mmol})$ in EtOAc $(75 \mathrm{~mL})$ was added IBX $(8 \mathrm{~g}, 28.57 \mathrm{mmol})$. The reaction mixture was refluxing for $3 \mathrm{~h}$ then cooled to rt and filtered over a Celite pad. The filtrate was concentrated under reduced pressure to provide aldehyde $16(1.92 \mathrm{~g}, 97 \%)$ as colorless oil pure enough to be used without further purification. $\mathrm{R}_{f}=0.37$ (EtOAc/PE $\left.=3: 7\right)$; IR (neat) $v_{\max } 1720 \mathrm{~cm}^{-1} ;{ }^{1} \mathrm{H} \mathrm{NMR}\left(\mathrm{CDCl}_{3}\right.$, $300 \mathrm{MHz}) \delta 9.80(\mathrm{t}, 1 \mathrm{H}, J=1.2 \mathrm{~Hz}), 7.37(\mathrm{~d}, 1 \mathrm{H}, J=2.1 \mathrm{~Hz}), 7.09(\mathrm{dd}, 1 \mathrm{H}, J=2.4,8.4 \mathrm{~Hz})$, $6.82(\mathrm{~d}, 1 \mathrm{H}, J=8.4 \mathrm{~Hz}), 3.86(\mathrm{~s}, 3 \mathrm{H}), 2.90-2.85(\mathrm{~m}, 2 \mathrm{H}), 2.78-2.72(\mathrm{~m}, 2 \mathrm{H}) ;{ }^{13} \mathrm{C} \mathrm{NMR}\left(\mathrm{CDCl}_{3}\right.$, $75 \mathrm{MHz}) \delta 201.3,154.5,134.1,133.1,128.4,112.1,111.7,56.4,45.3,26.9$; HRMS (DCI, $\left.\mathrm{CH}_{4}\right): m / z 243.0022[\mathrm{M}+\mathrm{H}]^{+}\left(\right.$calcd for $\left.\mathrm{C}_{10} \mathrm{H}_{12} \mathrm{BrO}_{2}, 243.0021\right)$.

1-(3-Bromo-4-methoxyphenyl)-7-(4-(tert-butyldimethylsilyloxy)phenyl)hept-4-yn-3-ol (19). To a stirred solution of alkyne $17(0.385 \mathrm{~g}, 1.48 \mathrm{mmol})$ in dried THF $(15 \mathrm{~mL})$ at $-78{ }^{\circ} \mathrm{C}$ under $\mathrm{N}_{2}$ was added dropwise $n$-BuLi (1.6 M in hexane, $1.11 \mathrm{~mL}, 1.78 \mathrm{mmol})$. After stirring for $45 \mathrm{~min}$ at $-78{ }^{\circ} \mathrm{C}$ a solution of aldehyde $16(0.359 \mathrm{~g}, 1.48 \mathrm{mmol})$ in dry THF $(5 \mathrm{~mL})$ was added. The resulting mixture was allowed to warm up to $\mathrm{rt}$ and was stirred for another $90 \mathrm{~min}$, then quenched with satd aq $\mathrm{NH}_{4} \mathrm{Cl}$ solution and the aqueous layer was extracted with $\mathrm{Et}_{2} \mathrm{O}$. The combined organic layers were washed with satd aq $\mathrm{NH}_{4} \mathrm{Cl}$ solution, $\mathrm{H}_{2} \mathrm{O}$ and brine then dried over $\mathrm{Na}_{2} \mathrm{SO}_{4}$ and then concentrated under reduced pressure. The crude residue was purified by column chromatography on silica gel $(\mathrm{EtOAc} / \mathrm{PE}=1: 9)$ to provide propargyl alcohol $19(0.65$ $\mathrm{g}, 87 \%)$ as a light yellow oil. $\mathrm{R}_{f}=0.38(\mathrm{EtOAc} / \mathrm{PE}=3: 7)$; IR (neat) $v_{\max } 3390,1500,1260 \mathrm{~cm}^{-}$ ${ }^{1}$; ${ }^{1} \mathrm{H} \mathrm{NMR}\left(\mathrm{CDCl}_{3}, 300 \mathrm{MHz}\right) \delta 7.38(\mathrm{~d}, 1 \mathrm{H}, J=2.1 \mathrm{~Hz}), 7.07(\mathrm{dd}, 1 \mathrm{H}, J=8.4,2.1 \mathrm{~Hz}), 7.07$ $(\mathrm{d}, 2 \mathrm{H}, J=8.7 \mathrm{~Hz}), 6.54(\mathrm{~d}, 1 \mathrm{H}, J=8.4 \mathrm{~Hz}), 6.76(\mathrm{~d}, 2 \mathrm{H}, J=8.7 \mathrm{~Hz}), 4.31(\mathrm{tt}, 1 \mathrm{H}, J=6.3,1.9$ Hz), $3.87(\mathrm{~s}, 3 \mathrm{H}), 2.76(\mathrm{t}, 2 \mathrm{H}, J=7.5 \mathrm{~Hz}), 2.66(\mathrm{t}, 2 \mathrm{H}, J=7.8 \mathrm{~Hz}), 2.48(\mathrm{td}, 2 \mathrm{H}, J=7.5,1.9$ $\mathrm{Hz}), 1.98-1.87$ (m, 2H), 0.97 (s, 9H), 0.17 (s, 6H) ; ${ }^{13} \mathrm{C} \mathrm{NMR}\left(\mathrm{CDCl}_{3}, 75 \mathrm{MHz}\right) \delta 154.3,154.2$, 135.3 (2C), 133.4, 129.4, 128.5, 120.0, 112.1, 111.6, 85.6, 81.7, 61.9, 56.4, 39.6, 34.3, 30.3, 25.8, 21.2, 18.3, -4.3. HRMS (DCI, $\mathrm{CH}_{4}$ ): $\mathrm{m} / 2501.1442[\mathrm{M}-\mathrm{H}]^{+}$(calcd for $\mathrm{C}_{26} \mathrm{H}_{34} \mathrm{BrO}_{3} \mathrm{Si}$, $501.1461)$.

(4Z)-(3-Bromo-4-methoxyphenyl)-7-(4-(tert-butyldimethylsilyloxy)phenyl)hept-4-en-3-ol (20). To a solution of alkyne $19(52 \mathrm{mg}, 0.1 \mathrm{mmol})$ in EtOH $(3.3 \mathrm{~mL})$ was added Lindlar catalyst 
$(7.8 \mathrm{mg}, 15 \% \mathrm{w} / \mathrm{w})$ and the reaction mixture was subjected to $6 \mathrm{~atm}$ of hydrogen at $\mathrm{rt}$ for $18 \mathrm{~h}$. Filtration over a Celite pad and concentration under vacuum yield alkene $\mathbf{2 0}$ (53 mg, 99\%) as a light yellow oil pure enough to be used in the next step without further purification. $\mathrm{R}_{f}=0.32$ $($ EtOAc/PE $=2: 8)$; IR (neat) $v_{\max } 3360,1610 \mathrm{~cm}^{-1} ;{ }^{1} \mathrm{H} \mathrm{NMR}\left(\mathrm{CDCl}_{3}, 300 \mathrm{MHz}\right) \delta 7.35(\mathrm{~d}, 1 \mathrm{H}$, $J=2.1 \mathrm{~Hz}), 7.05(\mathrm{dd}, 1 \mathrm{H}, J=8.1,2.1 \mathrm{~Hz}), 6.99(\mathrm{~d}, 2 \mathrm{H}, J=8.7 \mathrm{~Hz}), 6.80(\mathrm{~d}, 1 \mathrm{H}, 8.1 \mathrm{~Hz}), 6.76$ $(\mathrm{d}, 2 \mathrm{H}, J=8.7 \mathrm{~Hz}), 5.52(\mathrm{dtd}, 1 \mathrm{H}, J=10.8,7.8,0.9 \mathrm{~Hz}), 5.39(\mathrm{ddt}, 1 \mathrm{H}, J=10.8,8.4,1.2 \mathrm{~Hz})$, 4.22 (dt, 1H, $J=8.4,6.6 \mathrm{~Hz}), 3.87$ (s, 3H), 2.69-2.45 (m, 4H), 2.41-2.25 (m, 2H), 1.79 (dtd, $1 \mathrm{H}, J=13.5,6.9,8.4 \mathrm{~Hz}), 1.58(\mathrm{dtd}, 1 \mathrm{H}, J=13.5,6.9,9.3 \mathrm{~Hz}), 0.97(\mathrm{~s}, 9 \mathrm{H}), 0.18(\mathrm{~s}, 6 \mathrm{H}) ;{ }^{13} \mathrm{C}$ NMR $\left(\mathrm{CDCl}_{3}, 75 \mathrm{MHz}\right) \delta 154.0,153.8,135.6,134.1,133.2,133.1,131.1,129.5,128.3,119.9$, 111.9, 111.4, 66.5, 56.2, 38.6, 34.9, 30.4, 29.8, 25.7, 18.2, -4.4. HRMS (DCI, $\left.\mathrm{CH}_{4}\right): \mathrm{m} / \mathrm{z}$ $504.1682[\mathrm{M}]^{+}$(calcd for $\left.\mathrm{C}_{26} \mathrm{H}_{37} \mathrm{BrO}_{3} \mathrm{Si}, 504.1695\right)$.

(Z)-4-(7-(3-Bromo-4-methoxyphenyl)-5-hydroxyhept-3-enyl)phenol (14). To a solution of silylether 20 (0.698 g, $1.38 \mathrm{mmol})$ in dry THF (15 mL) was added dropwise TBAF (1M solution in THF, $2.76 \mathrm{mmol}$ ). After stirring for $30 \mathrm{~min}$ at $0{ }^{\circ} \mathrm{C}$, the reaction mixture was quenched with sat aq $\mathrm{NaHCO}_{3}(5 \mathrm{~mL})$, and the aqueous layer was extracted with $\mathrm{Et}_{2} \mathrm{O}$. The combined organic layers were washed with satd aq $\mathrm{NaHCO}_{3}, \mathrm{H}_{2} \mathrm{O}$ and brine, then dried over $\mathrm{Na}_{2} \mathrm{SO}_{4}$ and concentrated under reduced pressure. The crude residue was purified by column chromatography on silica gel $\left(1 \% \mathrm{MeOH}\right.$ in $\left.\mathrm{CH}_{2} \mathrm{Cl}_{2}\right)$ to provide aldehyde $14(0.51 \mathrm{~g}, 94 \%)$ as a colorless gum. $\mathrm{R}_{f}=0.22\left(1 \% \mathrm{MeOH}\right.$ in $\left.\mathrm{CH}_{2} \mathrm{Cl}_{2}\right)$; IR (neat) $v_{\max } 3315,1610,1510 \mathrm{~cm}^{-1} ;{ }^{1} \mathrm{H}$ $\operatorname{NMR}\left(\mathrm{CDCl}_{3}, 300 \mathrm{MHz}\right) \delta 7.33(\mathrm{~d}, 1 \mathrm{H}, J=2.1 \mathrm{~Hz}), 7.04(\mathrm{dd}, 1 \mathrm{H}, J=8.4,2.1 \mathrm{~Hz}), 7.00(\mathrm{~d}$, $2 \mathrm{H}, J=8.7 \mathrm{~Hz}), 6.80(\mathrm{~d}, 1 \mathrm{H}, J=8.4 \mathrm{~Hz}), 6.75(\mathrm{~d}, 2 \mathrm{H}, J=8.7 \mathrm{~Hz}), 5.53(\mathrm{dt}, 1 \mathrm{H}, J=10.9,7.7$ $\mathrm{Hz}), 5.40(\mathrm{dd}, 1 \mathrm{H}, J=10.9,9 \mathrm{~Hz}), 4.17$ (dt, 1H, $J=8.7,7.2 \mathrm{~Hz}), 3.87$ (s, 3H), 2.71-2.47 (m, $4 \mathrm{H}), 2.36-2.28(\mathrm{~m}, 2 \mathrm{H}), 1.76(\mathrm{dtd}, 1 \mathrm{H}, J=13.4,8.6,6.9 \mathrm{~Hz}), 1.53(\mathrm{ddt}, 1 \mathrm{H}, J=13.4,9.4,6.9$ $\mathrm{Hz}) ;{ }^{13} \mathrm{C} \mathrm{NMR}\left(\mathrm{CDCl}_{3}, 75 \mathrm{MHz}\right) \delta 154.5,154.1,135.6,133.3,133.2,132.9,131.8,130.0$, 128.4, 115.3, 112.0, 111.5, 66.8, 56.4, 38.2, 34.6, 30.4, 30.1; HRMS (DCI, CH $\left.{ }_{4}\right) m / z .390 .0838$ $[\mathrm{M}]^{+}$(calcd for $\mathrm{C}_{20} \mathrm{H}_{23} \mathrm{BrO}_{3}, 390.0831$ ).

\section{(Z)-16-Methoxy-2-oxa-1(1,3),3(1,4)-dibenzenacyclodecaphan-6-en-8-ol (21).}

By conventional heating: To a solution of phenol 20 (406 mg; $1.04 \mathrm{mmol})$ in anhydrous pyridine (53 mL) was added $\mathrm{K}_{2} \mathrm{CO}_{3}(287 \mathrm{mg} ; 2.08 \mathrm{mmol})$. The mixture was warmed to $90{ }^{\circ} \mathrm{C}$ and $\mathrm{CuO}$ (207 mg; $2.6 \mathrm{mmol}$ ) was added. After heating was for $48 \mathrm{~h}$, the reaction mixture was cooled to rt and concentrated under reduced pressure. The residue was dissolved in EtOAc and neutralized by addition of $10 \%$ aq $\mathrm{NaHSO}_{3}$ solution. The aqueous layer was extracted with 
EtOAc and the combined organic layers were washed with $10 \%$ aq $\mathrm{NaHSO}_{3}$ solution, water and brine, then dried over $\mathrm{Na}_{2} \mathrm{SO}_{4}$ and concentrated under reduced pressure. The crude residue was purified by column chromatography on silica gel $($ EtOAc/pentane $=3: 7)$ to provide compound 21 (226 $\mathrm{mg}, 70 \%$ ) as a gum.

By microwave heating: A mixture of 20 (31 mg, $\left.7.9210^{-5} \mathrm{~mol}\right), \mathrm{K}_{2} \mathrm{CO}_{3}\left(22 \mathrm{mg}, 1.5810^{-4} \mathrm{~mol}\right)$ and $\mathrm{CuO}\left(16 \mathrm{mg}, 1.9810^{-4} \mathrm{~mol}\right)$ in pyridine $(4 \mathrm{~mL})$ was heated at $150^{\circ} \mathrm{C}$ under microwave irradiation in a sealed tube for $4 \mathrm{~h}$. The reaction mixture was treated as described above to yield, after column chromatography, the expected compound $21(20 \mathrm{mg}, 81 \%) . \mathrm{R}_{f}=0.21(\mathrm{EtOAc} / \mathrm{PE}$ $=3: 7) ; \mathrm{IR}$ (neat) $v_{\max } 3400,1590,1520,1500,1220 \mathrm{~cm}^{-1} ; \mathrm{RMN}^{1} \mathrm{H}\left(\mathrm{CDCl}_{3}, 300 \mathrm{MHz}\right)_{-} \delta 7.31$ (dd, 1H, $J=8.1,2.1 \mathrm{~Hz}), 7.07-6.98(\mathrm{~m}, 3 \mathrm{H}), 6.77$ (d, 1H, $J=8.4 \mathrm{~Hz}), 6.62$ (dd, 1H, $J=8.1,2.1$ $\mathrm{Hz}$ ), 5.53 (dddd, $1 \mathrm{H}, J=11.1,10.8,4.8,0.9 \mathrm{~Hz}$ ), 5.43 (ddd, $1 \mathrm{H}, J=10.8,7.1,0.9 \mathrm{~Hz}), 5.38$ (d, $1 \mathrm{H}, \mathrm{J}=2.1 \mathrm{~Hz}), 3.94$ (s, 3H), 3.59 (ddd, $1 \mathrm{H}, J=9.9,7.2,2.7 \mathrm{~Hz}), 3.04$ (ddd, 1H, $J=12.9,5.7$, $2.1 \mathrm{~Hz}$.), 2.67 (dd, $1 \mathrm{H}, J=16.2,9.3 \mathrm{~Hz}$ ), 2.71-2.50 (m, 4H), 1.74 (dddd, $1 \mathrm{H}, J=14.7,8.7,10.2$, $1.8 \mathrm{~Hz}), 1.49-1.25(\mathrm{~m}, 1 \mathrm{H}) ; \mathrm{RMN}{ }^{13} \mathrm{C}\left(\mathrm{CDCl}_{3}, 75 \mathrm{MHz}\right) \delta 155.8,151.7,146.3,139.8,135.3$, 134.0, 133.3, 130.7, 130.6, 124.6, 123.2, 121.2, 115.7, 111.7, 66.4, 56.3, 38.7, 34.7, 32.9, 27.7; HRMS (DCI, $\mathrm{CH}_{4}$ ) m/z $310.1569[\mathrm{M}]^{+}$(calcd for $\mathrm{C}_{20} \mathrm{H}_{22} \mathrm{O}_{3}, 310.1561$ ).

(6Z,8E)-16-Methoxy-2-oxa-1(1,3),3(1,4)-dibenzenacyclodecaphane-6,8-diene (22a) and (6E,8E)-16-Methoxy-2-oxa-1(1,3),3(1,4)-dibenzenacyclodecaphane-6,8-diene (22b). To a solution of alcohol 21 (227 mg; 0,731 mmol) in $\mathrm{CH}_{2} \mathrm{Cl}_{2}(10 \mathrm{~mL})$ at $0{ }^{\circ} \mathrm{C}$ were added dropwise $\mathrm{NEt}_{3}(306 \mu \mathrm{L}, 2.19 \mathrm{mmol})$ and $\mathrm{CH}_{3} \mathrm{SO}_{2} \mathrm{Cl}(68 \mu \mathrm{L}, 0.878 \mathrm{mmol})$. After stirring at $0{ }^{\circ} \mathrm{C}$ for 90 min and at $\mathrm{rt}$ for $3 \mathrm{~h}$, the reaction mixture was quenched with satd aq $\mathrm{NH}_{4} \mathrm{Cl}$ solution. The aqueous layer was extracted with $\mathrm{CH}_{2} \mathrm{Cl}_{2}$. The combined organic layers were washed with satd aq $\mathrm{NH}_{4} \mathrm{Cl}$ solution, $\mathrm{H}_{2} \mathrm{O}$ and brine then dried over $\mathrm{Na}_{2} \mathrm{SO}_{4}$ and concentrated under vacuum. Column chromatography on silica gel $\left(\mathrm{CH}_{2} \mathrm{Cl}_{2} /\right.$ pentane $\left.=3 / 7\right)$ of the residue to yielded a $60 / 40$ mixture of isomers 22a and 22b (161 mg, 75\%). Preparative HPLC (Eluent: heptane $/ \mathrm{CH}_{2} \mathrm{Cl}_{2}$ $=95 / 5$. Flowrate: $15 \mathrm{~mL} / \mathrm{min})$ allowed isolation of pure isomer $\mathbf{2 2 \mathbf { a }}(94 \mathrm{mg}, 44 \%)$ and $\mathbf{2 2 \mathbf { b }}(38$ $\mathrm{mg}, 13 \%)$ as colorless crystals. $\mathrm{R}_{f}=0.31\left(\mathrm{CH}_{2} \mathrm{Cl}_{2} /\right.$ pentane $\left.=2: 8\right)$. For $22 \mathbf{a}$ : colorless block $\left(\mathrm{CH}_{2} \mathrm{Cl}_{2}\right) ; \mathrm{mp}>200^{\circ} \mathrm{C}$; UV (MeOH) $\lambda_{\max }(\log \varepsilon) 277$ (3.26) nm, 247 (3.98) nm; IR (neat) $v_{\max }$ $2960 \mathrm{~cm}^{-1} ;{ }^{1} \mathrm{H} \mathrm{NMR}\left(\mathrm{CDCl}_{3}, 300 \mathrm{MHz}, 25^{\circ} \mathrm{C}\right) \delta$ 7.23-6.88 (broad coalescent signals, $\left.4 \mathrm{H}\right)$, $6.75(\mathrm{~d}, 1 \mathrm{H}, J=8.1 \mathrm{~Hz}), 6.64(\mathrm{dd}, 1 \mathrm{H}, J=8.1,2.1 \mathrm{~Hz}), 5.97(\mathrm{dd}, 1 \mathrm{H}, J=11.1,10.8 \mathrm{~Hz}), 5.71$ (ddd, $1 \mathrm{H}, J=15,10.8,0.6 \mathrm{~Hz}), 5.53(\mathrm{dt}, 1 \mathrm{H}, J=15.3,7.8 \mathrm{~Hz}), 5.45(\mathrm{~d}, 1 \mathrm{H}, J=2.4 \mathrm{~Hz}), 5.31$ $(\mathrm{dt}, 1 \mathrm{H}, J=11.1,8.6 \mathrm{~Hz}), 3.94(\mathrm{~s}, 3 \mathrm{H}), 3.01(\mathrm{~d}, 2 \mathrm{H}, J=7.8 \mathrm{~Hz}), 2.40(\mathrm{brs}, 2 \mathrm{H}) ;{ }^{13} \mathrm{C} \mathrm{NMR}$ $\left(\mathrm{CDCl}_{3}, 75 \mathrm{MHz}, 25^{\circ} \mathrm{C}\right) \delta$ (four $\mathrm{C}$ not detectable because of a coalescence at $\mathrm{rt}$ ) 155.1, 151.6, 
$146.5,139.5,132.6,131.6,130.7,128.7,128.4,120.4,116.8,111.3,56.3,36.2,35.2,32.1$; HRMS (DCI, $\left.\mathrm{CH}_{4}\right): m / z 293.1553[\mathrm{M}+\mathrm{H}]^{+}$(calcd for $\left.\mathrm{C}_{20} \mathrm{H}_{21} \mathrm{O}_{2}, 293.1542\right)$.

For 22b : colorless needles $\left(\mathrm{CH}_{2} \mathrm{Cl}_{2}\right)$; $\mathrm{mp}>200^{\circ} \mathrm{C}$; $\mathrm{UV}(\mathrm{MeOH}) \lambda_{\max }(\log \varepsilon) 275$ (2.87) nm, 237 (3.98) nm; IR (neat) $v_{\max } 2920,1580 \mathrm{~cm}^{-1} ;{ }^{1} \mathrm{H} \mathrm{NMR}\left(\mathrm{CDCl}_{3}, 300 \mathrm{MHz}\right) \delta 7.08$ (d, 2H, $J$ $=8.4 \mathrm{~Hz}), 6.97(\mathrm{~d}, 2 \mathrm{H}, J=8.4 \mathrm{~Hz}), 6.81(\mathrm{~d}, 1 \mathrm{H}, J=8.1 \mathrm{~Hz}), 6.70(\mathrm{dd}, 1 \mathrm{H}, J=8.1,2.1 \mathrm{~Hz})$, $5.74(\mathrm{~d}, 1 \mathrm{H}, J=2.1 \mathrm{~Hz}), 5.71-5.58(\mathrm{~m}, 2 \mathrm{H}), 5.21(\mathrm{dt}, 1 \mathrm{H}, J=14.7,7.5 \mathrm{~Hz}), 5.14(\mathrm{dt}, 1 \mathrm{H}, J=$ 14.4, $7.2 \mathrm{~Hz}$ ), 3.95 (s, 3H), 3.13 (d, 2H, $J=7.5 \mathrm{~Hz}), 2.89$ (t, 2H, $J=6.6 \mathrm{~Hz}), 2.46$ (q, 2H, $J=$ $6.9 \mathrm{~Hz}) ;{ }^{13} \mathrm{C} \mathrm{NMR}\left(\mathrm{CDCl}_{3}, 75 \mathrm{MHz}\right) \delta 153.8,150.6,146.5,138.8,134.0,133.1,133.0,130.9$, 130.8, 129.8, 123.5, 120.9, 116.4, 111.6, 56.3, 36.3, 34.3, 33.9. HRMS (DCI, $\left.\mathrm{CH}_{4}\right): \mathrm{m} / \mathrm{z}$ $293.1554[\mathrm{M}+\mathrm{H}]^{+}$(calcd for $\mathrm{C}_{20} \mathrm{H}_{21} \mathrm{O}_{2}, 293.1542$ ).

Demethylation of Macrocycles 22a-b. To a solution of a 60/40 mixture of 22a-22b (96 mg, $0.33 \mathrm{mmol})$ in DMF (5 mL) was added EtSNa $(70 \mathrm{mg}, 0.82 \mathrm{mmol})$. The reaction mixture was refluxed for $1.5 \mathrm{~h}$. After cooling to $0{ }^{\circ} \mathrm{C}, 5 \%$ aq $\mathrm{HCl}$ solution was added, the aqueous layer was extracted with EtOAc and the combined organic layers were washed with 5\% aq $\mathrm{HCl}$ solution, $\mathrm{H}_{2} \mathrm{O}$ and brine. The solution was dried over $\mathrm{Na}_{2} \mathrm{SO}_{4}$ and concentrated under vacuum. Column chromatography on silica gel (EtOAc/PE = 1:9) provided a mixture of phenols 1, 23 and 24 (77 $\mathrm{mg}, 84 \%)$. Flash chromatography $\left(\mathrm{CH}_{2} \mathrm{Cl}_{2} /\right.$ pentane $=10 / 90$ to $\left.40 / 60\right)$ allowed the isolation of derivative $\mathbf{2 4}$ (22 $\mathrm{mg}, 24 \%$ ) as a light yellow solid.

For (7E,9Z)-2-oxa-1(1,3),3(1,4)-dibenzenacyclodecaphane-7,9-dien-16-ol (24). $\quad \mathrm{R}_{f}=0.23$ $\left(\mathrm{CH}_{2} \mathrm{Cl}_{2} /\right.$ pentane $\left.=1: 1\right) ; \mathrm{IR}$ (neat) $v_{\max } 3406,1651 \mathrm{~cm}^{-1} ;{ }^{1} \mathrm{H} \mathrm{NMR}\left(\mathrm{CD}_{3} \mathrm{OD}, 300 \mathrm{MHz}\right) \delta 7.37$ $(\mathrm{d}, 2 \mathrm{H}, J=8.5 \mathrm{~Hz}), 7.08(\mathrm{~d}, 2 \mathrm{H}, J=8.5 \mathrm{~Hz}), 6.75(\mathrm{~d}, 1 \mathrm{H}, J=8.1 \mathrm{~Hz}), 6.56(\mathrm{dd}, 1 \mathrm{H}, J=8.1$, $2.0 \mathrm{~Hz}), 6.07(\mathrm{~d}, 1 \mathrm{H}, J=2.0 \mathrm{~Hz}), 6.00(\mathrm{~d}, 1 \mathrm{H}, J=11.3 \mathrm{~Hz}), 5.81(\mathrm{dd}, 1 \mathrm{H}, J=11.3,8.8 \mathrm{~Hz})$, $5.60(\mathrm{dd}, 1 \mathrm{H}, J=15.2,8.8 \mathrm{~Hz}), 5.56(\mathrm{~m}, 1 \mathrm{H}), 2.68(\mathrm{t}, 2 \mathrm{H}, J=6.3 \mathrm{~Hz}), 2.10(\mathrm{q}, 2 \mathrm{H}, J=6.1 \mathrm{~Hz})$, 1.67 (brs, $2 \mathrm{H}) ;{ }^{13} \mathrm{C}$ NMR $\left(\mathrm{CD}_{3} \mathrm{OD}, 125 \mathrm{MHz}\right) \delta 156.4,150.5,146.0,140.9,137.5,132.6,130.7$, 128.4, 128.2 (2C), 124.7, 123.6, 118.7, 116.9, 36.4, 31.6, 29.6; HRMS (DCI, CH $): m / z$ $278.1314[\mathrm{M}]^{+}$: (calcd for $\left.\mathrm{C}_{19} \mathrm{H}_{18} \mathrm{O}_{2}, 278.1307\right)$.

(Z)-2-Oxa-1(1,3),3(1,4)-dibenzenacyclodecaphan-6-ene-16,8-diol (13). To a solution of alcohol 21 (141 mg, $0.45 \mathrm{mmol}$ ) in DMF (7 mL) was added EtSNa (143 mg, $1.6 \mathrm{mmol})$. The reaction mixture was refluxed for $3.5 \mathrm{~h}$. After cooling to $0{ }^{\circ} \mathrm{C}, 5 \%$ aq $\mathrm{HCl}$ solution was added, the aqueous layer was extracted with EtOAc and the combined organic layers were washed with $5 \%$ aq $\mathrm{HCl}$ solution, $\mathrm{H}_{2} \mathrm{O}$ and brine. The solution was dried over $\mathrm{Na}_{2} \mathrm{SO}_{4}$ and concentrated under vacuum. The residue was purified by column chromatography on silica gel $(0.2 \%$ of 
$\mathrm{MeOH}$ in $\left.\mathrm{CH}_{2} \mathrm{Cl}_{2}\right)$ yielded phenol $13(106 \mathrm{mg}, 79 \%)$ as a white solid. $\mathrm{R}_{f}=0.22\left(\mathrm{CH}_{2} \mathrm{Cl}_{2} / \mathrm{MeOH}\right.$ =99:1); IR (neat) $v_{\max } 3432,1590 \mathrm{~cm}^{-1} ;{ }^{1} \mathrm{H} \mathrm{NMR}\left(\mathrm{CDCl}_{3}, 300 \mathrm{MHz}\right) \delta 7.30(\mathrm{dd}, 1 \mathrm{H}, J=8.4$, $2.1 \mathrm{~Hz}), 7.09-7.05(\mathrm{~m}, 1 \mathrm{H}), 7.02-6.96(\mathrm{~m}, 2 \mathrm{H}), 6.81(\mathrm{~d}, 1 \mathrm{H}, J=8.1 \mathrm{~Hz}), 6.58(\mathrm{dd}, 1 \mathrm{H}, J=8.1$, $2.1 \mathrm{~Hz}), 5.53(\mathrm{dddd}, 1 \mathrm{H}, J=12.1,11.0,4.7,1.0 \mathrm{~Hz}), 5.43(\mathrm{ddd}, 1 \mathrm{H}, J=11.0,6.6,1.4 \mathrm{~Hz}), 5.37$ (d, $1 \mathrm{H}, J=2.1 \mathrm{~Hz}), 3.54(\mathrm{ddd}, 1 \mathrm{H}, J=9.6,6.6,3 \mathrm{~Hz}), 3.05(\mathrm{ddd}, 1 \mathrm{H}, J=12.8,5.7,2.4 \mathrm{~Hz})$, $2.65(\mathrm{dd}, 1 \mathrm{H}, J=16.2,9.6 \mathrm{~Hz}), 2.52-2.29$ (m, 4H), 1.72 (dddd, $1 \mathrm{H}, J=14.7,9.7,8.4,2.1 \mathrm{~Hz}$ ), 1.46 (dddd, $1 \mathrm{H}, J=14.7,9.6,3.3,2.1 \mathrm{~Hz}) ;{ }^{13} \mathrm{C} \mathrm{NMR}\left(\mathrm{CDCl}_{3}, 75 \mathrm{MHz}\right) \delta 155.8,149.6,142.7$, 140.2, 134.4, 134.0, 133.6, 131.0, 130.6, 124.4, 123.1, 122.1, 115.4, 115.0, 66.0, 38.6, 34.8, 33.0, 27.8; HRMS (DCI, $\left.\mathrm{CH}_{4}\right): \mathrm{m} / z 297.1480[\mathrm{M}+\mathrm{H}]^{+}\left(\right.$calcd for $\left.\mathrm{C}_{19} \mathrm{H}_{21} \mathrm{O}_{3}, 297.1491\right)$.

(6Z,8E)-2-Oxa-1(1,3),3(1,4)-dibenzenacyclodecaphane-6,8-dien-16-yl methanesulfonate (25a) and (6E,8E)-2-Oxa-1(1,3),3(1,4)-dibenzenacyclodecaphane-6,8-dien-16-yl methanesulfonate (25b). To an ice cooled solution of $\mathbf{1 3}\left(59 \mathrm{mg}, 210^{-4} \mathrm{~mol}\right)$ in $\mathrm{CH}_{2} \mathrm{Cl}_{2}(3 \mathrm{~mL})$ were added $\mathrm{NEt}_{3}$ $(167 \mu \mathrm{L}, 1.2 \mathrm{mmol})$ and $\mathrm{CH}_{3} \mathrm{SO}_{2} \mathrm{Cl}\left(46 \mu \mathrm{L}, 610^{-4} \mathrm{~mol}\right)$. The reaction mixture was stirred at 0 ${ }^{\circ} \mathrm{C}$ for $2 \mathrm{~h}$ and at $\mathrm{rt}$ for $1 \mathrm{~h}$, then quenched with satd aq $\mathrm{NH}_{4} \mathrm{Cl}$ solution; The aqueous layer was extracted with $\mathrm{CH}_{2} \mathrm{Cl}_{2}$ and the combined organic layers were washed with satd aq $\mathrm{NH}_{4} \mathrm{Cl}$ solution, $\mathrm{H}_{2} \mathrm{O}$ and brine, dried over $\mathrm{Na}_{2} \mathrm{SO}_{4}$ and concentrated under vacuum. The crude residue was purified by column chromatography on silica gel $\left(\mathrm{CH}_{2} \mathrm{Cl}_{2}\right)$ to provide a $60 / 40$ mixture of isomers 25a and 25b (57 mg, 80\%). $\mathrm{R}_{f}=0.24\left(\mathrm{CH}_{2} \mathrm{Cl}_{2} / \mathrm{PE}=1: 1\right)$. IR (neat) $v_{\max } 1500,1361$, $1173 \mathrm{~cm}^{-1}$; For 25a (from a mixture): ${ }^{1} \mathrm{H} \mathrm{NMR}\left(\mathrm{CDCl}_{3}, 300 \mathrm{MHz}\right) \delta 7.15(\mathrm{~d}, 1 \mathrm{H}, J=8.1 \mathrm{~Hz})$, $6.69(\mathrm{dd}, 1 \mathrm{H}, J=8.1,2.1 \mathrm{~Hz}), 5.98(\mathrm{dd}, 1 \mathrm{H}, J=10.9,10.9 \mathrm{~Hz}), 5.58(\mathrm{~d}, 1 \mathrm{H}, J=2.0 \mathrm{~Hz}), 5.70$ $(\mathrm{dd}, 1 \mathrm{H}, J=15.0,10.6 \mathrm{~Hz}), 5.54(\mathrm{dt}, 1 \mathrm{H}, J=15.2,7.7 \mathrm{~Hz}), 5.33(\mathrm{dt}, 1 \mathrm{H}, J=10.9,8.6 \mathrm{~Hz}), 3.34$ $(\mathrm{s}, 3 \mathrm{H}), 3.05(\mathrm{~d}, 2 \mathrm{H}, J=7.7 \mathrm{~Hz}), 2.40$ (brs, $2 \mathrm{H}) ;{ }^{13} \mathrm{C} \mathrm{NMR}\left(\mathrm{CDCl}_{3}, 75 \mathrm{MHz}\right) \delta$ (four C not detectable because of a coalescence at rt)154.2, 152.8, 140.0, 139.4, 135.3, 131.7, 131.1, 129.2, 128.6, 123.9, 121.0, 118.0, 38.5, 36.1, 35.0, 31.9. HRMS (DCI, $\left.\mathrm{CH}_{4}\right): m / z 357.1156[\mathrm{M}+\mathrm{H}]^{+}$ (calcd for $\mathrm{C}_{20} \mathrm{H}_{21} \mathrm{O}_{4} \mathrm{~S}, 357.1161$ ). For 25b (from a mixture): ${ }^{1} \mathrm{H}$ NMR $\left(\mathrm{CDCl}_{3}, 300\right.$ MHz) $\delta 7.19(\mathrm{~d}, 1 \mathrm{H}, J=8.2 \mathrm{~Hz}), 7.10(\mathrm{~d}, 2 \mathrm{H}, J=8.5 \mathrm{~Hz}), 6.93(\mathrm{~d}, 2 \mathrm{H}, J=8.5 \mathrm{~Hz}), 6.77$ (dd, $1 \mathrm{H}, J=8.2,2.1 \mathrm{~Hz}), 5.85(\mathrm{~d}, 1 \mathrm{H}, J=2.1 \mathrm{~Hz}), 5.75-5.66(\mathrm{~m}, 2 \mathrm{H}), 5.29-5.10(\mathrm{~m}, 2 \mathrm{H}), 3.32$ (s, $3 \mathrm{H}), 3.17(\mathrm{~d}, 2 \mathrm{H}, J=7.9 \mathrm{~Hz}), 2.91(\mathrm{t}, 2 \mathrm{H}, J=6.7 \mathrm{~Hz}), 2.46(\mathrm{q}, 2 \mathrm{H}, J=6.9 \mathrm{~Hz}) ;{ }^{13} \mathrm{C} \mathrm{NMR}$ $\left(\mathrm{CDCl}_{3}, 75 \mathrm{MHz}\right) \delta 153.4,152.5,140.1,139.4,135.4,134.4,132.7,131.01,130.4,128.8$, $124.0,122.9,121.5,117.5,38.5,36.2,34.0,33.7$.

(6E,8E)-2-Oxa-1(1,3),3(1,4)-dibenzenacyclodecaphane-6,8-dien-16-ol (23) and (6Z,8E)-2Oxa-1(1,3),3(1,4)-dibenzenacyclodecaphane-6,8-dien-16-ol or Tedarene A (1). To a solution 
of 25a-b (42 mg, $\left.1.1810^{-4} \mathrm{~mol}\right)$ in dioxane $(3.5 \mathrm{~mL})$ were added successively $\mathrm{MeOH}(3.5 \mathrm{~mL})$ and aq $20 \% \mathrm{NaOH}$ solution $(9 \mathrm{~mL})$. The reaction mixture was stirred at $60{ }^{\circ} \mathrm{C}$ for $3 \mathrm{~h}$ then cooled to $0{ }^{\circ} \mathrm{C}$. Aqueous $3 \mathrm{M} \mathrm{HCl}$ solution was added and the aqueous layer was extracted with $\mathrm{CH}_{2} \mathrm{Cl}_{2}$. The combined organic layers were washed with aq $3 \mathrm{M} \mathrm{HCl}$ solution, $\mathrm{H}_{2} \mathrm{O}$ and brine, dried over $\mathrm{Na}_{2} \mathrm{SO}_{4}$ and concentrated under vacuum. Column chromatography on silica gel $\left(\mathrm{CH}_{2} \mathrm{Cl}_{2}\right)$ of the residue yielded a 60/40 mixture of isomers 1 and 23 (22 mg, 67\%). Preparative HPLC (Eluent: heptane /iPrOH = 99:1; Flowrate: $20 \mathrm{~mL} / \mathrm{min}$ ) allowed isolation of pure isomer $\mathbf{1}(12.7 \mathrm{mg}, 38.5 \%)$ and $\mathbf{2 3}(7.6 \mathrm{mg}, 23 \%)$ as colorless solids. $\mathrm{R}_{f}=0.23\left(\mathrm{CH}_{2} \mathrm{Cl}_{2} /\right.$ pentane $\left.=1: 1\right)$. For 23 : colorless block crystals $\left(\mathrm{CH}_{2} \mathrm{Cl}_{2}\right)$; mp 156-157 ${ }^{\circ} \mathrm{C}$; $\mathrm{UV}(\mathrm{MeOH}) \lambda_{\max }(\log \varepsilon) 271$ (3.60) $\mathrm{nm}, 241(4.42) \mathrm{nm}$; IR (neat) $v_{\max } 3512,1593 \mathrm{~cm}^{-1}$; ${ }^{1} \mathrm{H}$ NMR $\left(\mathrm{CD}_{3} \mathrm{OD}, 300 \mathrm{MHz}\right) \delta 7.13(\mathrm{~d}$, $2 \mathrm{H}, J=8.4 \mathrm{~Hz}), 6.92(\mathrm{~d}, 2 \mathrm{H}, J=8.4 \mathrm{~Hz}), 6.70(\mathrm{~d}, 1 \mathrm{H}, J=8.0 \mathrm{~Hz}), 6.57(\mathrm{dd}, 1 \mathrm{H}, J=8.0,2.1$ $\mathrm{Hz}), 5.70(\mathrm{~d}, 1 \mathrm{H}, J=2.1 \mathrm{~Hz}), 5.66-5.57(\mathrm{~m}, 2 \mathrm{H}), 5.20-5.10(\mathrm{~m}, 2 \mathrm{H}), 3.05(\mathrm{~d}, 2 \mathrm{H}, J=7.5 \mathrm{~Hz})$, $2.91(\mathrm{t}, 2 \mathrm{H}, J=6.8 \mathrm{~Hz}), 2.46(\mathrm{q}, 2 \mathrm{H}, J=7 \mathrm{~Hz}) ;{ }^{13} \mathrm{C} \mathrm{NMR}\left(\mathrm{CD}_{3} \mathrm{OD}, 125 \mathrm{MHz}\right) \delta 155.2,150.6$, 144.6, 140.1, 134.8, 134.2, 133.0, 132.0, 131.6, 131.0, 124.3, 122.1, 117.5, 116.6, 37.0, 35.0, 34.7; HRMS (DCI, $\mathrm{CH}_{4}$ ) : $\mathrm{m} / z$ 279.1396 [M+H] $]^{+}$(calcd for $\mathrm{C}_{19} \mathrm{H}_{19} \mathrm{O}_{2}, 279.1385$ ).

For tedarene $\mathrm{A}^{11}(\mathbf{1})$ : colorless block crystals $\left(\mathrm{CH}_{2} \mathrm{Cl}_{2}\right)$; mp 122-123 ${ }^{\circ} \mathrm{C}$; IR (neat) $v_{\max } 3451$, $1605 \mathrm{~cm}^{-1} ;{ }^{1} \mathrm{H}$ NMR $\left(\mathrm{CD}_{3} \mathrm{OD}, 300 \mathrm{MHz}, 25{ }^{\circ} \mathrm{C}\right) \quad \delta$ 7.34-6.83 (broad coalescent signals, $4 \mathrm{H}$ ), $6.65(\mathrm{~d}, 1 \mathrm{H}, J=7.9 \mathrm{~Hz}), 6.50(\mathrm{dd}, 1 \mathrm{H}, J=7.9,2.1 \mathrm{~Hz}), 5.94(\mathrm{dd}, 1 \mathrm{H}, J=11.4,10.4 \mathrm{~Hz}), 5.72$ $(\mathrm{dd}, 1 \mathrm{H}, J=15.1,11.1 \mathrm{~Hz}), 5.45(\mathrm{dt}, 1 \mathrm{H}, J=15.6,7.6 \mathrm{~Hz}), 5.42(\mathrm{~d}, 1 \mathrm{H}, J=2.1 \mathrm{~Hz}), 5.31(\mathrm{dt}$, $1 \mathrm{H}, J=11.0,8.3 \mathrm{~Hz}), 2.94(\mathrm{~d}, 2 \mathrm{H}, J=7.9 \mathrm{~Hz}), 2.40$ (brs, 2H) ; ${ }^{1} \mathrm{H}$ NMR $\left(\mathrm{CD}_{3} \mathrm{OD}, 300 \mathrm{MHz}\right.$, $\left.40^{\circ} \mathrm{C}\right) \delta 7.38(\mathrm{dd}, 1 \mathrm{H}, J=8.3,2.2 \mathrm{~Hz}), 7.04(\mathrm{dd}, 1 \mathrm{H}, J=8.0,2.1 \mathrm{~Hz}), 7.03(\mathrm{dd}, 1 \mathrm{H}, J=8.2,2.1$ $\mathrm{Hz}), 6.79(\mathrm{dd}, 1 \mathrm{H}, J=8.2,2.4 \mathrm{~Hz}), 6.63(\mathrm{~d}, 1 \mathrm{H}, J=7.8 \mathrm{~Hz}), 6.52(\mathrm{dd}, 1 \mathrm{H}, J=7.9,2.1 \mathrm{~Hz})$, $5.95(\mathrm{t}, 1 \mathrm{H}, J=11.0 \mathrm{~Hz}), 5.72(\mathrm{dd}, 1 \mathrm{H}, J=15.0,10.9 \mathrm{~Hz}), 5.47(\mathrm{~m}, 1 \mathrm{H}), 5.40-5.28(\mathrm{~m}, 1 \mathrm{H})$, $5.35(\mathrm{~d}, 1 \mathrm{H}, J=2 \mathrm{~Hz}), 3.08-2.99(\mathrm{~m}, 1 \mathrm{H}), 2.97-2.91(\mathrm{~m}, 2 \mathrm{H}), 2.51(\mathrm{td}, 1 \mathrm{H}, J=12.0,2.5 \mathrm{~Hz})$, $2 \mathrm{e} " .45-2.35(\mathrm{~m}, 2 \mathrm{H}) ;{ }^{13} \mathrm{C}$ NMR $\left(\mathrm{CD}_{3} \mathrm{OD}, 75 \mathrm{MHz}, 25^{\circ} \mathrm{C}\right) \delta$ (four C not detectable because of a coalescence at rt) 156.6, 151.7, 144.5, 140.9, 133.8, 131.8, 131.6, 129.6, 129.2, 121.6, 118.0, 116.4, 36.9, 36.0, 33.0; ${ }^{13} \mathrm{C} \mathrm{NMR}\left(\mathrm{CD}_{3} \mathrm{OD}, 75 \mathrm{MHz},-40^{\circ} \mathrm{C}\right) \delta 156.2,151.5,144.4,141.0$, 133.8, 133.3, 131.7, 131.5, 131.2, 129.6, 129.3, 125.5, 123.7, 121.6, 117.6, 116.0, 36.9, 35.9, 33.0; HRMS (DCI, $\mathrm{CH}_{4}$ ) : $m / z, 278.1298[\mathrm{M}]^{+}$(calcd for $\mathrm{C}_{19} \mathrm{H}_{18} \mathrm{O}_{2}, 278.1307$ ).

\section{ASSOCIATED CONTENTS}

\section{Supporting Information}

The Supporting Information is available free of charge on the ACS Publications website at DOI: 
${ }^{1} \mathrm{H}$ and ${ }^{13} \mathrm{C}$ NMR spectra of all new compounds. ${ }^{1} \mathrm{H}$ spectra of known compounds, X-ray

crystallographic data of 1, 22a, 22b and 23 (PDF).

$\mathrm{X}$-ray data for $1(\mathrm{CIF})$.

$\mathrm{X}$-ray data for 22a (CIF).

$\mathrm{X}$-ray data for $\mathbf{2 2 b}(\mathrm{CIF})$.

$\mathrm{X}$-ray data for $\mathbf{2 3}(\mathrm{CIF})$.

\section{AUTHOR INFORMATION}

\section{Corresponding Author}

*E-mail: bedos@chimie.ups-tlse.fr

\section{Notes}

The authors declare no competing financial interest.

\section{ACKNOWLEDGMENTS}

We thank the French 'Ministère de l'Enseignement Supérieur et de la Recherche' (grant to K.M.). Thanks are also due to the CNRS and the "Université Paul Sabatier" for financial support.

\section{REFERENCES}

(1) Mallinson, J.; Collins, I. Future Med. Chem. 2012, 4, 1409-1438.

(2) Marsault, E.; Peterson, M. L. J. Med. Chem. 2011, 54, 1961-2004.

(3) Giordanetto, F.; Kihlberg, J. J. Med. Chem. 2014, 57, 278-295.

(4) Lv, H.; She, G. Rec. Nat. Prod. 2012, 6, 321-333.

(5) Lv, H.; She, G. Nat. Prod. Commun. 2010, 5, 1687-1708.

(6) Sun, Y.; Kurokawa, M.; Miura, M.; Kakegawa, T.; Motohashi, S.; Yasukawa, K. In Studies in Natural Products Chemistry; Elsevier, 2016; Vol. 49, pp 157-187.

(7) Kasi, P. D.; Tamilselvam, R.; Skalicka-Woźniak, K.; Nabavi, S. F.; Daglia, M.; Bishayee, A.; Pazoki-toroudi, H.; Nabavi, S. M. Tumor Biol. 2016, 37, 13017-13028.

(8) Campbell, R. V. M.; Crombie, L.; Tuck, B.; Whiting, D. A. J. Chem. Soc. Chem. Commun. 1970, 18, 1206-1207.

(9) Nagai, M.; Kubo, M.; Fujita, M.; Inoue, T.; Matsuo, M. J. Chem. Soc. Chem. Commun. 1976, 10, 338-339

(10) Kubo, M.; Nagai, M.; Inoue, T. Chem. Pharm. Bull. (Tokyo) 1983, 31, 1917-1922.

(11) Costantino, V.; Fattorusso, E.; Mangoni, A.; Perinu, C.; Teta, R.; Panza, E.; Ianaro, A. J. Org. Chem. 2012, 77, 6377-6383.

(12) Egi, M.; Kawai, T.; Umemura, M.; Akai, S. J. Org. Chem. 2012, 77, 7092-7097.

(13) Nakao, Y.; Shirakawa, E.; Tsuchimoto, T.; Hiyama, T. J. Organomet. Chem. 2004, 68, 3701-3721. 
(14) Van Goor, F. F.; Burton, W. L. Pyrazinecarboxamide derivatives as epithelial sodium channel inhibitors and their preparation, pharmaceutical compositions and use for the treatment of cystic fibrosis and other chronic diseases. Apr 28, 2011 WO 2011050325 A1.

(15) Yokokawa, F.; Inaizumi, A.; Shioiri, T. Tetrahedron 2005, 61, 1459-1480.

(16) Rives, A.; Maraval, V.; Saffon-Merceron, N.; Chauvin, R. Chem. Eur. J. 2012, 18, 14702-17407.

(17) Amador, M.; Ariza, X.; Garcia, J.; Ortiz, J. Tetrahedron Lett. 2002, 43, 2691-2694.

(18) Castillo-Contreras, E. B.; Dake, G. R. Org. Lett. 2014, 16, 1642-1645.

(19) Keilitz, J.; Newman, S. G.; Lautens, M. Org. Lett. 2013, 15, 1148-1151.

(20) Shibuya, G. M.; Kanady, J. S.; Vanderwal, C. D. J. Am. Chem. Soc. 2008, 130, 1251412518.

(21) Jeong, B.-S.; Wang, Q.; Son, J.-K.; Jahng, Y. Eur. J. Org. Chem. 2007, 2007, 13381344.

(22) Shen, L.; Simmons, C. J.; Sun, D. Tetrahedron Lett. 2012, 53, 4173-4178.

(23) Kozikowski, A. P.; Tuckmantel, W. J. Org. Chem. 1991, 56, 2826-2837.

(24) Pattawong, O.; Salih, M. Q.; Rosson, N. T.; Beaudry, C. M.; Cheong, P. H.-Y. Org. Biomol. Chem. 2014, 12, 3303-3309.

(25) CCDC-1534576 (1), CCDC-1534577 (22a), CCDC-1534578 (22b) and CCDC1534579 (23) contain the supplementary crystallographic data for this paper. These data can be obtained free of charge from the Cambridge Crystallographic Data Centre via www.ccddc.cam.ac.uk/data_request/cif.

(26) Gonzalez, G. I.; Zhu, J. J. Org. Chem. 1999, 64, 914-924.

(27) Zhao, W.; Feng, X.; Ban, S.; Lin, W.; Li, Q. Bioorg. Med. Chem. Lett. 2010, 20, 41324134.

(28) Salih, M. Q.; Beaudry, C. M. Org. Lett. 2013, 15, 4540-4543.

(29) Feutrill, G. I.; Mirrington, R. N. Tetrahedron Lett. 1970, 11, 1327-1328.

(30) Tripathi, S.; Chan, M.-H.; Chen, C. Bioorg. Med. Chem. Lett. 2012, 22, 216-221.

(31) Trost, B. M.; Yeh, V. S. C.; Ito, H.; Bremeyer, N. Org. Lett. 2002, 4, 2621-2623.

(32) Englung, E., Elaine. Synthetic Progress Toward Parvis temonine, Spiroxins A and B, and Generation of Palmarumycin Analogues. Ph.D. Dissertation, University of Pittsburgh, PA, 2008. 
Table of Contents/Abstract Graphic

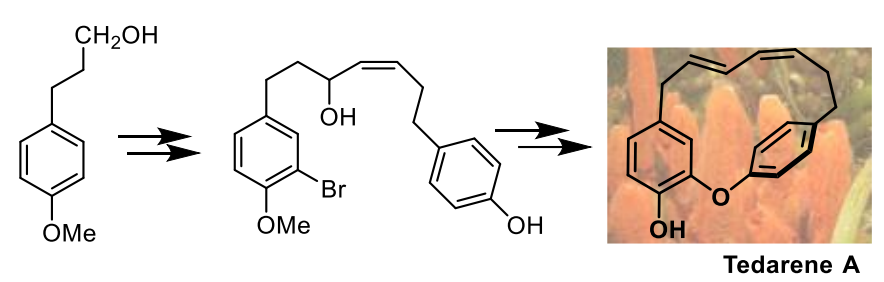

